\title{
Barriers and Drivers of Renewable Energy Penetration in Rural Areas
}

\author{
Dalia Streimikiene*(D), Tomas Baležentis*D, Artiom Volkov $\mathbb{D}$, Mangirdas Morkūnas, Agnè Žičkienè \\ and Justas Streimikis
}

Citation: Streimikiene, D.

Baležentis, T.; Volkov, A.;

Morkūnas, M.; Žičkienè, A.;

Streimikis, J. Barriers and Drivers of Renewable Energy Penetration in Rural Areas. Energies 2021, 14, 6452. https://doi.org/10.3390/en14206452

Academic Editors: T M Indra Mahlia and Amela Ajanovic

Received: 23 August 2021

Accepted: 5 October 2021

Published: 9 October 2021

Publisher's Note: MDPI stays neutral with regard to jurisdictional claims in published maps and institutional affiliations.

Copyright: (c) 2021 by the authors. Licensee MDPI, Basel, Switzerland This article is an open access article distributed under the terms and conditions of the Creative Commons Attribution (CC BY) license (https:// creativecommons.org/licenses/by/ $4.0 /)$.
Lithuanian Centre for Social Sciences, Institute of Economics and Rural Development, A. Vivulskio Str. 4A-13, LT-03220 Vilnius, Lithuania; artiom.volkov@laei.lt (A.V.); mangirdas.morkunas@evaf.vu.lt (M.M.); agne.zickiene@laei.lt (A.Ž.); justas.streimikis@gmail.com (J.S.)

* Correspondence: dalia.streimikiene@lei.lt (D.S.); tomas.balezentis@laei.lt (T.B.)

Abstract: The paper deals with the exposition of the main barriers and drivers of renewable energy usage in rural communities. Climate change mitigation is causing governments, policymakers, and international organizations worldwide to embark on policies, leading to increased use of renewable energy sources and improvement of energy efficiency. Climate change mitigation actions, including the Green Deal strategy in the EU, require satisfying the expanding energy demand and complying with the environmental restrictions. At the same time, the prevailing market structure and infrastructure relevant to the energy systems are undergoing a crucial transformation. Specifically, there has been a shift from centralized to more decentralized and interactive energy systems that are accompanied by a low-carbon energy transition. Smart Grid technology and other innovations in the area of renewable energy microgeneration technologies have enabled changes in terms of the roles of energy users: they can act as prosumers that are producing and consuming energy at the same time. Renewable energy generation that is allowing for deeper involvement of the citizens may render higher social acceptance, which, in turn, fuels the low-carbon energy transition. The collective energy prosumption in the form of energy cooperatives has become a widespread form of renewable energy initiatives in rural communities. Even though renewable energy consumption provides a lot of benefits and opportunities for rural communities, the fast penetration of renewables and energy prosumption encounter several important barriers in the rural areas. This paper analyses the main barriers and drivers of renewable energy initiatives in rural areas and provides policy implications for the low-carbon energy transition in rural areas.

Keywords: renewable energy; energy cooperatives; rural areas; agriculture; energy prosumers; barriers; drivers; success factors; policies

\section{Introduction}

In order to implement the EU Clean Energy Packages and Green Deal, it is necessary to make energy transitions more inclusive, fair, and democratic, and the diverse forms of energy citizenship can help achieve this. It is especially essential to ensure a low-carbon transition and fast penetration in rural areas that are distinguished by a low population density and extensive energy use for farming purposes. Energy citizenship and other energy initiatives can be important drivers in this transition process.

Citizenship is a status. First, being a citizen has a range of rights and responsibilities, and it focuses on the agency and practices that recognize the citizenship. Agency focuses on the individual's self-identity as a citizen and emphasizes the thought and actions that were exercised. The definition of Energy Citizenship by Ryghaug et al. (2018) [1] and DevineWright (2007) [2] includes both individual and collective forms of energy citizenship with a focus on their agency around the material and non-material practices and actions, often termed as performative participation [3]. 
The concept of energy citizenship is based on the participation of citizens in the clean energy transition, and it requires analyzing the levels of possible participation in the energy system of rural communities [4]. It is also necessary to address the ethics of participation, i.e., (un)just decisions that are being practiced by local authorities. Often, local authorities do not always recognize the local citizen-led energy citizenship actions or practices that are appropriate for citizen participation in the state-led energy transition projects [5]. This highlights the dynamic rational nature of agency and illustrates the need for recognition processes to involve state/private service providers as well as citizens since the power to define citizen status and activity lies in the citizens themselves and institutions and actors with which they work or from which they obtain services. If the right of the citizens to participate is largely translated to political participation, confined to voting only or confining them to users/consumers, then only the users' feedback and involvement can be confined simply to the tokenism and non-participative forms and will not become a part of the democratic governance [6].

With the rise of the good governance agenda, now citizen participation requires meeting citizenship rights and human agency for citizen voices to be heard as well as to allow them to influence and hold state/other service providers accountable for both decision-making processes and their outcomes that affect them. In some EU member states, a different form of energy collectives can be seen, where energy citizens are utilizing the full "citizen power" of Arnstein's ladder by being self-organized with a bottom-up and common good approach to make decisions by themselves (independent decision making), not just influence them $[7,8]$.

Based on the participation point of view, it is possible to categorize energy citizenship on the basis of doing, thinking, and organizing as theorized in Radtke et al. (2018) [3]. Each category of energy citizenship is characterized by different combinations of competencies, meanings, and materials. This results in an ideal set of working typologies of energy citizenships according to the practices of citizens (e.g., competencies, meaning, materials). The practices of citizens depend on the interactions around the energy technology, the understanding of clean energy, and the competencies to exercise their democratic rights to participate in decision-making processes. This also includes the knowledge of clean energy/energy saving/technical issues of energy and the competencies to implement this in everyday lives. The energy system's materiality (especially ownership) influences the practices of citizens, their agency, and the possibilities and the type and form of participation in a specific way and results in limited participation, cooperation exchange, competition, or conflict. The ownership of materiality highly predisposes what agency a citizen has in the clean energy transition, e.g., a person in a rental house does not have the agency to decide whether to install a smart meter or solar power on the roof of her/his house. The material participation (individual/collective form) can include active participation in using low-carbon technologies and community programs, such as solar, green housing, smart meter, smart technology, renewable energy communities, etc., prosumers, virtual storage, peer-2-peer exchange, while non-material participation can be, for example, learning, training, advocacy, consulting at the individual level or collective forms, such as energy networks, energy campaigns, forums for energy transition-related dialogues/debates, etc. The form, level, and modality of participation may vary for the state-led projects, as in Arnstein's participation ladder, and may change for bottom-up citizen-led programs, such as clean energy collectives or cooperatives. Significant work has been conducted on an individual scale (individual or household level) of energy citizenship, and more recently, the focus on collective forms of energy citizenship in energy systems, studied under different labels and multiple dimensions, has been increasing. These include renewable energy communities, renewable energy initiatives, energy cooperatives, grassroots innovations, or community energy. There are three main citizen-led types of participation within the energy sector: Community and Cooperative Energy Projects, Public Activism and Campaigning, and Local Authority and Citizen Collaborations [9]. 
Many rural communities are waiting for opportunities to expand the existing local policy instruments (such as building retrofitting, improving waste-management, and participatory budgeting), expand digitization and use of smart systems, as well as implement community energy projects [10]. Local government and regional energy agencies are as well keen to innovate and increase the use of renewable energy sources (RES), decentralize the energy supply, and promote energy democracy. In order to create community energy systems, such as solar parks, it is necessary to create suitable regulations to enable citizens themselves to become shareholders and thus prosumers. The municipalities should continue to develop many awareness-building workshops/training to enable local citizens to cut their environmental footprint and increase their knowledge about how citizens themselves can reduce the emissions, improve the use of RES, and adapt to climate change.

There is a problem of energy inequality and lack of agency for certain energy citizenship that is manifested in particular places [11,12]. Some injustices can be linked to the institutional or other external factors that have been produced elsewhere at mesoand landscape-scale-enabling conditions for energy citizenship for certain communities of place or interests while disabling for others. Therefore, the energy justice concept is very important in terms of distribution, recognition, and procedure. There are eleven principles of energy justice: availability, affordability, participation, due process, transparency and accountability, sustainability, intergenerational equity, intra-generational equity, responsibility, resistance, and respect $[13,14]$.

In order to understand the enabling and disabling conditions that are activating and muting certain energy citizenship in rural areas, the barriers of renewable energy initiatives in the form of rural energy cooperatives need to be addressed as well. The principles of energy justice can be used to advance the understanding of social practices of existing and potential energy citizens while operationalizing the energy citizenship at the micro-meso scales and state governance at meso and macro scales. In such view, the distributional justice will help to define where in the municipalities and regions, the energy transition (in terms of ownership and access to low-carbon energy technologies and services) is benefitting certain communities and activating certain energy citizenship and where it has been muted now and in the past. Looking at the state governance and institutional mapping frames through the procedural and recognition justice lens can help to understand what contextual specificities (e.g., institutional structure, legal regimes, existing possibilities to participate) exist for the process and mechanisms that are used to develop energy transition visions, related policies, and their implementation while looking at who is included and excluded in that process, enabling and disabling past, existing, and potential conditions for certain energy citizenships [15].

The local authorities across the EU continue to play a critical role in energy transitions and activating energy citizenship through more inclusive approaches to citizen participation in energy transition strategies and policy formulation and implementations through projects and programs [16]. Even though it has been acknowledged that successful actions of collaborative, participatory planning lead to social justice, there are no clear operational mechanisms that would ensure these linkages within the practices that were initiated by the national or local authorities in the domain of energy policy $[17,18]$. Though renewables offer a solution to low-carbon futures, the past and present energy decisions may have been made in a "moral vacuum" with (un)equal citizen participation, leading to (un)just transition [11]. Though renewable energy initiatives in rural areas in the form of energy cooperatives can provide many benefits for rural communities, there are many barriers to renewable energy initiatives $[19,20]$. The policies and measures are developed to overcome these barriers, but they are not always successful. There are also important success factors of renewable energy initiatives in rural areas that require attention, as renewable energy initiatives in the form of renewable energy cooperatives can be the main drivers of a low-carbon energy transition in rural areas.

Several studies are analyzing the drivers and barriers of renewable energy penetration [21-24], the barriers and determinants of energy cooperatives [25-27], or barriers of 
collective energy presumption [28-32]; however, there are no studies addressing these issues in rural areas, as the main studies analyze the barriers and drivers of renewable energy penetration or energy prosumption in urban areas. Therefore, this paper aims to address this gap and analyze the main barriers of renewable energy initiatives and policies to overcome these barriers in rural communities. The main input of the paper is the analysis of barriers and success factors of renewable energy initiatives in rural areas and the assessment of policies to overcome the barriers and promote renewables.

Section 2 of the paper presents methods and data. In Section 3, the problems related to a renewable energy transition in rural areas were identified. Section 4 introduces energy prosumption options in rural areas and types of energy cooperatives. Section 5 analyzes barriers and success factors of renewable energy initiatives in rural areas. Section 6 assesses the policies and measures to overcome these barriers of renewable energy initiatives in rural areas. Finally, Section 7 provides conclusions.

\section{Methods and Data}

A literature review was performed for the analysis of the current state of knowledge in the field. In order to ensure the methodological precision of the research, the SALSA framework was followed (Amo et al., 2018). The SALSA framework consists of the four following steps: Search, Appraisal, Synthesis, and Analysis. The Search step was carried out on the Web of Science database on the topic "Renewable energy initiatives" along with combinations of "Rural communities", "Barriers of renewables", and "Energy prosumption". After reading the abstracts in the Appraisal step, only the studies covering content that corresponded to the problem under analysis were selected for further analysis. In order to expand the search, a snowballing method was used. After reading the selected articles, the main questions were identified in the Synthesis step, and the papers were grouped according to the several main areas: problems of a renewable energy transition in rural areas, energy prosumption options and energy cooperatives in rural areas, barriers and drivers of renewable energy initiatives in rural areas, policies and measures to overcome barriers of renewable energy barriers in rural areas.

\section{Transition to Renewable Energy in Rural Areas}

The agriculture sector is still highly reliant on fossil fuels. Thus, basically, the agricultural processes are oriented towards the technologies that are transforming fossil energy into agri-food products. Nevertheless, climate change and the subsequent international agreements on climate change mitigation require reducing the share of fossil fuels in the energy mix for agriculture. This has been addressed in strategies such as the EU Green Deal and the corresponding policy targets. Therefore, it is necessary to ensure the transition of agriculture from fossil fuels into renewable energy sources. First, it is necessary to restructure the agriculture sector to use the electricity that has been generated from renewable energy sources (RES), such as wind, solar, biogas, etc. This implies shifting towards technologies that allow turning electricity that has been produced from RES into agri-food products [33]. Renewable electricity can provide important services for the farm at costs that are similar to those incurred when using fossil fuels. However, the shifting of agriculture from fossil to renewable energy sources requires vast public participation. Overall, an increase in the utilization of renewable electricity on farms is a part of the overall low-carbon transition scheme in agriculture that requires substantial transformations of the current agricultural systems to achieve the overall sustainability of the agricultural sector $[33,34]$.

It is also possible to transform renewable electricity into fuel. However, it is a rather costly and technologically complicated process. This implies that more financial and other resources are required. It is possible to use electric power for the electrolysis of water and the production of hydrogen, which can be applied as fuel for transportation in agriculture. However, this technology creates several problems, such as energy storage and conversion, requires many various resources, and is not appropriate for agriculture systems. It is 
possible to solve problems linked to energy storage needs by transforming hydrogen into liquid fuels, but this is a complex and expensive technological process as well. There is another way for utilizing hydrogen in the methanation process (transforming $\mathrm{CO}_{2}$ into $\mathrm{CH}_{4}$ ), which may easily join the gas distribution network [35].

The most productive approach is adapting the agricultural sector for the direct use of renewable electricity as much as possible. In such a way, modern renewable energy sources can be exploited in the most efficient mode without intermediate processing losses. Electric motors can be used to generate mechanical power instead of thermal engines, as they are more efficient. However, the farmers often do not know how to use renewable electricity directly in the key agricultural processes [36]. It is necessary to stress that the adaptation of the farming processes to renewable electricity use requires a variety of activities, and there are many informative, financial, behavioral, and other barriers that are hampering the penetration of renewable electricity at the farm level. Thus, currently, electricity is mainly being used for lighting, heating, refrigeration, and irrigation in farms and does not play an important role in agricultural production processes [37].

First, in order to ensure the transition to renewables in agriculture, it is necessary to restructure the mechanization processes in order to replace fossil fuel-based vehicles with electric ones. An increase in energy efficiency is a key issue in agriculture, as the reduction in energy consumption in agriculture has a positive impact on pollution reduction and causes a less negative impact on the degradation of the soil. Therefore, a transition to agriculture that is based on renewable electricity requires a gradual switch from fossil fuels to renewable energy sources and replacing the existing machinery with more modern and more efficient in terms of energy consumption [33].

It is well known that due to the constant depletion of the humus layer of soil, mineral nutrients are necessary for agriculture. Nitrogen, phosphorous, calcium, and potassium are the main fertilizers that are widely used in modern agriculture for the restoration of soil fertility. As the production of mineral fertilizers is an energy-intensive process, the adaptation of the agriculture sector is necessary to reduce the consumption of mineral fertilizers. The implementation of conservative agriculture practices is necessary, requiring huge efforts in recycling and reusing [38]. The reduction in the use of fertilizers in agricultural processes has a positive impact on environmental pollution reduction, especially reducing groundwater contamination by nitrates and phosphates [39].

The production of pesticides, such as fertilizers, is an energy-intensive process, causing significant greenhouse gas emissions. In addition, though the pesticides are necessary in order to kill the pests, the overuse of pesticides sometimes has a negative impact on the environment, consumers of food, and farmers. Therefore, pest management strategies need to be improved by reducing the use of pesticides and avoiding dangerous pesticides due to high health and environmental risks [39].

It is possible to switch the production of fertilizers and pesticides by using fossil fuels for renewable energy, but the problem is how to turn renewable electricity into pesticides. There are new and environmentally friendly ways for synthesizing fertilizers; however, there are no other ways to synthesize pesticides other than the preparation from fossil fuel-based "raw chemicals". The transformation of the chemical industry that is based on biomass-derived products and electrochemical processes is also necessary to ensure the sustainability of agricultural systems [40]. Such transformation of chemical industries can be treated as a "sustainable" pesticide production method. The future decline in fossil fuel use will lead to a rise in the prices of chemical fertilizers and pesticides, pressuring the agriculture sector to transition to organic farming and significantly reduce industrial chemicals consumption [41].

There is a serious problem of water aquifer depletion available in modern agriculture, and though water pumping can be conducted using electricity from renewable energy sources, the problem still exists. It is possible to use freshwater by obtaining it through the desalination of water or the condensation of humidity from the atmosphere. These are very energy-intensive and expensive processes that are not able to compete with traditional 
freshwater supply sources. In order to produce freshwater as a by-product using renewable energy sources, energy storage technologies are very important. However, the amount of freshwater that is possible to produce through the desalination or condensation of humidity from the atmosphere will be very limited, considering the huge demand of water necessary for the irrigation processes; therefore, water-efficient agricultural practices are necessary. Renewable energy can help solve water supply problems in agriculture, and it is possible to substitute fossil fuels that are used in farms for pumping and piping [42].

The transition from fossil to renewable energy in agriculture can start from the farm becoming an energy producer or prosumer instead of a consumer. An individual renewable plant can be located on farmland, or the collective renewable energy plants can be built for entire rural communities by implementing various renewable energy initiatives [43]. The farmers can also lease their land for big distant renewable energy plants owned by consumer cooperatives that were created in cities. Currently, there have been created several business models to promote renewable energy presumption [44].

The farmers have been supported for many years by the government to install wind, solar, hydro, etc., plants on their land in order to ensure covering their main energy needs with renewable energy sources. Small renewable energy plants do not usually have any negative impact on the environment; however, the energy generated by these plants is limited and sometimes not able to satisfy even the energy needs of a farm. For example, the use of small wind or mini-hydropower plants as sources of electricity for irrigation has been a popular technology in farms during the first half of the 20th century. There are always possibilities on farms to use agricultural waste and animal waste for energy generation. Wood is a traditional renewable energy source that has been used by farms for many years. Therefore, small renewable energy plants and agriculture and animal waste can deliver a steady electric power supply for the farm. It is necessary to stress that wind and solar PV plants are more efficient in transforming renewable energy into electricity on a farm [45].

The big wind parks as well as big solar plants are more efficient and more profitable; however, they are causing many more environmental problems in rural areas [46]. Large wind parks can produce noise and raise the average temperature of the soil, and these effects need to be taken into account when locating big wind parks in the vicinity of the farms. The big renewable energy projects often encounter NIMBY phenomena in rural areas [47]. The energy citizenship concept is useful in terms of these barriers, and various forms of ownership of big renewable energy projects provide many opportunities for profitable renewable energy initiatives in rural communities.

It is necessary to remember that the traditional business of farms is farming, and farmers usually do not have the knowledge and experience in producing renewable electricity or running renewable energy plants. Hence, the transformation of the farm into a small power plant is not the best way to ensure the fast penetration of renewable energy sources in the agricultural sector. At the moment, there is no current aim to create energetically "self-sufficient" farms that can produce all of the energy necessary to satisfy the farm's energy needs [48]. The scale factors are favoring the emergence of new business models in this field, and renewable energy production to supply at the farm level is mainly vectored through the power grid. This approach enables more efficient decentralized energy supply and production systems, providing better energy supply security [49].

A renewable energy cooperative is another attractive option, providing many opportunities for farmers. Land leasing for big PV systems is another attractive source of income for farmers. In general, there are various renewable energy initiatives in rural communities that provide many benefits for farmers in terms of additional income from the electricity sales and renewable electricity to cover the energy needs of the farm [50].

Based on the results of the European Commission 6th framework project "RAMSES" [33], conservation agriculture can reduce the energy demand by $60 \%$ from the conventional farming level and can be entirely based on renewables; however, for such transformation of agricultural systems, additional policies and measures are necessary, ranging from eco- 
nomic to regulatory, informative, etc. Energy citizenship and other forms of participation can be an important driver and facilitator of renewable energy initiatives in rural areas.

Renewable energy in rural areas can become an essential driver for agri-food systems transformation and ensure climate resilience and net-zero strategies in the agricultural sector. Renewable energy sources can also enhance food and water security, drive agricultural productivity, and offer much needed socio-economic benefits in recovering agriculture and other sectors from COVID-19.

Climate and energy-smart agri-food practices that are based on renewable energy sources can increase agricultural productivity, food chain decarbonization, and the security of food supply. The acceleration of renewable energy solutions in sustainable agricultural practices will also boost economic growth and create jobs in a sustainable agro-industry, addressing critical development challenges of Sustainable Development Goals (SDGs) in developing and developed countries. The role of renewable energy sources in agri-food system transformations is systematized in Figure 1.

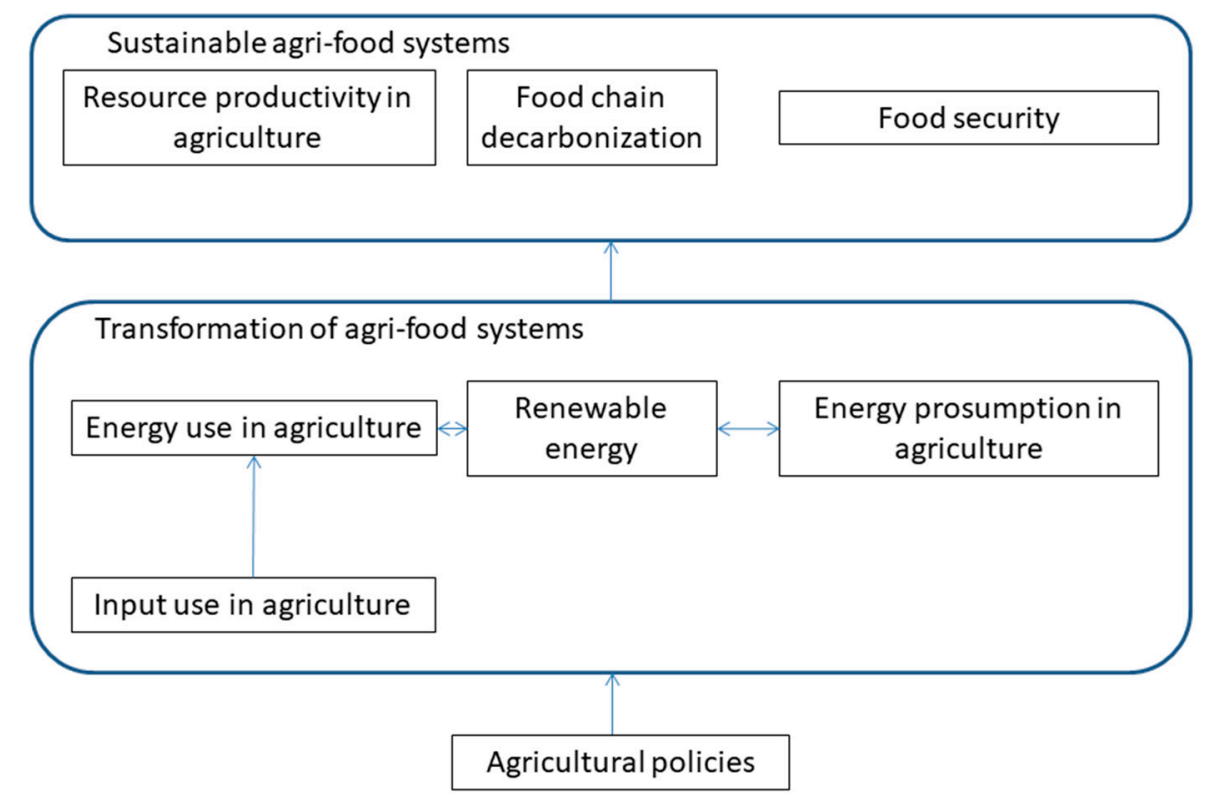

Figure 1. The role of renewables in the transformation of agri-food systems. Source: created by the authors.

Therefore, in arrangement with renewable energy production and consumption, conservation agriculture is the main development trend in the future agriculture sector [51]. The agriculture sector will be completely "weaned" from fossil fuels in the future, and the energy cooperatives, including other forms of energy prosumption in rural areas, can support this new type of agriculture development.

\section{Renewable Energy Ownership and Prosumption in Rural Areas}

Due to the growing energy demand and low-carbon transition goals, the energy sector is undergoing a transition to decentralized and interactive energy systems, in which energy consumers are also playing the role of energy prosumers [52]. It is necessary to distinguish between "active energy prosumers" and "passive energy prosumers". Passive energy prosumers are becoming prosumers due to specific external influences or due to the decisions of other people. Controversially, active energy prosumers decide to use renewable energy technologies purposefully and are not influenced by other people's decisions [53]. To summarize, the shift to the prosumer status creates many opportunities for individuals and communities to become more actively engaged in energy systems and take responsibility for the type and role of energy sources in their daily lives [54]. The low-carbon energy transition and penetration of specific RES technologies, as well as the 
development of ownership forms of energy systems, depend on the political processes that are available in the country and are supported by legislation and economic incentives [55].

The citizen ownership of RES is a current alternative ownership form in private or state-owned energy companies [56]. Community energy is one type of citizen ownership in the renewable energy sector [57]. Community energy is a specific form of an intentionally established community or community of choice $[45,58,59]$. The energy communities can be defined in terms of their spatial distribution (place and non-place-based ones) and scope of activity (single- and multi-purpose ones) [60,61]. It is possible to distinguish several more complicated types of citizen ownership models that have been discussed by [62]. The communities where all the participants are located within a compact locus are termed as local ones. These are opposed to distant communities that do not require residence or other activities within a certain location $[63,64]$. The common good ownership communities are established to use the proceeds from a RES project for other development purposes. The unlimited private profit ownership indicates that the proceeds are distributed among the owners without any imposed regulations concerning profitability [65]. The limited private profit ownership is the one where regulation is in effect (either voluntarily or not) or energy consumers are the owners [66].

An energy cooperative is the most common and fast-growing form of energy communities, especially in rural areas [67]. This type of RES ownership is most popular in countries where RES and community energy initiatives are well advanced. The establishment of proper conditions to institute energy communities [68,69] based on energy cooperatives is essential, especially in rural regions [70]. The idea of "smart villages" is particularly relevant in this case [70]. The energy cooperatives provide a big potential for the fast penetration of RES (biomass and biogas, solar, wind, hydro, etc.) in rural territories. There are tremendous opportunities for the use of organic waste for energy generation in line with the circular economy approach [71].

The growing energy demand in rural communities is pushing farmers to use energy more efficiently, switch to renewables from fossil fuels, and the policymakers are encouraging the development of climate change mitigation strategies in rural territories [72]. Therefore, the future development of rural territories and the economic and social development of rural communities are closely linked to the fast penetration of RES. The agricultural holdings are responsible for food production and can act as renewable energy users and producers [44], including activities within the framework of renewable energy cooperatives. Earlier studies $[45,73]$ have shown that the profitability of renewable energy cooperatives is dependent on the energy supply and demand patterns of cooperative members. The other drivers of energy cooperatives' profitability are market conditions, such as electricity price and transmission and the dynamics of distribution fees [74,75]. The energy, the availability of energy storage options, and e-mobility chargers are important drivers in this context as well.

In the discussion of RES ownership forms and the development of RES cooperatives in rural communities, energy prosumption plays an important role. In discussing the transformations linked to the transition to energy prosumer, it is useful to discuss the concept of prosumerism in the context of the "energy culture" change in the rural areas [76]. Energy culture can be considered an interaction between a farmer's material objects, agricultural and energy consumption practices, and their norms, which has an impact on their attitudes and behavior $[77,78]$. Farmer's material objects include installations, buildings, infrastructure, technologies, etc., that are owned and controlled by the farmer. Various agricultural processes and activities of a farmer have an impact on energy consumption. The norms are the farmer's expectations linked to the energy consumption and the services that have been delivered by the energy sources. The farmer's arrangement of material objects, practices, and norms forms the farmer's energy culture and reveals specific energy consumption patterns, including energy conservation, energy efficiency improvement, use of renewables and other innovations, etc. [79-82]. The energy culture of a farmer is also affected by external influences. The farmers can set up their own renewable energy systems 
and directly seek to become prosumers, or farmers can move into homes that already have renewable energy generation technologies installed [83,84].

There are individual and collective forms of energy prosumption. Sometimes, the collective actions within a specific rural community provide for the establishment of community-scale RES microgeneration plants by means of a cooperative model [85]. The energy culture of farmers plays an important role in this case as well. It can be a small group of farmers at the core of a RES project to initiate the progress with other rural community members that are coming on board at the later stages of RES project development and offering their shares to support the RES initiative in rural communities [86]. The funding of these renewable energy initiatives can be achieved via municipal or state grants, community member shares, etc. $[87,88]$.

There are other forms of community-initiated collective prosumerism, such as the emergence of clusters. The clustering option provides possibilities for individual prosumers to cooperate with each other and improve the collective interests of the energy community by selling RES electricity surplus, exchanging it with other prosumers, or storing it for later use $[89,90]$. There are several models of collective prosumers, depending on the initiator of the RES project. The RES project can be initiated by a community or external party. The RES project can be on multi-site, built on RES microgeneration technologies, owned by several farmers collectively, or constructed on a focal site in the case of several collectively possessed RES technologies. Considering why collective prosumerism is evolving, especially in rural communities, and defining the barriers and drivers of it, it is very important to prepare policies and measures and create a favorable environment for other industries to respond to a rapid rise in demand for RES projects [91,92].

Energy prosumption is mainly associated with renewable electricity, but sometimes, it can be related to the heating sector or even transportation. The term renewable energy technology describes a technology that is compatible with the use of the RES [93,94].

There are differences between renewable energy initiatives and collective energy prosumption in urban and rural areas. A smart city concept is more advanced than a smart village concept; however, in urban and rural areas, renewable energy initiatives are growing and becoming more and more attractive, despite important barriers hampering renewable energy initiatives and energy prosumption. In the next section, the main barriers and motives of renewable energy penetration in rural areas will be systematized based on the literature review.

\section{Barriers and Motives for RES Initiatives in Rural Areas}

Although there can be identified many reasonable advantages of renewable energy usage and collective prosumption in rural areas, these practices are still not widespread, given economic, social, institutional, regulatory, behavioral, and psychological factors [21-24,95-97]. There are still some minor economic obstacles to the acceptance of RES technologies, which are often linked to the comparatively high installation costs of these technologies [23]; however, based on IRENA assessments, the cost of electricity from renewable energy technologies has been falling steadily, and even dramatically, in recent years. This has especially been the case since 2000 with the rise of solar and wind power generation as viable commercial options. Nowadays, power generation from renewable sources and technologies has become increasingly competitive around the world. There are 15-20 years of payback for the investment in renewable energy technologies in some countries, and the operational costs of renewables are not well comprehended or quite complicated to calculate for potential consumers. Nevertheless, it is necessary to highlight that public support measures are important to popularize renewable energy technologies in their development stage, but in later stages, public support plays a minor role [98].

The main economic motives to implement RES in rural communities are linked to the economic savings or additional income (these appear respectively through lower fuel bills and public subsidies) [21-23]. The installation of modern advanced technologies has a positive impact on the increase in the farmer's property value. Moreover, the energy 
presumption allows generating additional income from energy sales. The additional income can be generated by farmers from land leasing for the installation of large solar or wind parks, etc. In addition, the economic motive to install renewable energy technologies is that switching from fossil fuels to renewable energy sources will lower the costs of agricultural production due to the high prices of fossil fuels. Moreover, the use of organic waste from agricultural production and animal waste for energy generation allows obtaining additional economic benefits for the farmers $[99,100]$.

There are many socio-political, regulatory, and environmental barriers to renewable energy penetration in rural areas $[30,55]$. The main reason RES technologies are not being implemented faster is the regulations that protect big fossil energy producers from free competition due to their high lobbying power.

The lack of attention from local authorities, as well as unstable political support and changing policies to promote the use of renewables or community RES initiatives, hamper the penetration of RES. Moreover, due to low income and high electricity prices, high poverty, and a high inequality level in rural communities, renewable energy initiatives are stagnating. Insufficient local community engagement and participation are other important social barriers, accompanied by the Not In My Back Yard (NYMBY) phenomenon in local communities, meaning that communities are resisting the RES projects that are implemented in the near area regardless of their positive or negative impacts [47]. The low capabilities of the community leaders to preserve the interest and participation of community members in daily work related to the RES technology licensing, financing, and management are crucial barriers. At the same time, the regional government is dependent, and the ineffectiveness of regional governance due to its high dependence on the national level hampers the penetration of renewables. There is a lack of incentives, and the business models to support prosumption are unclear, underdeveloped, and there is a lack of openness from the vendors of technologies, which has a negative impact on the participation of end users in the RES technologies testing and provision of feedback [101]. Sometimes, the environmental benefits of RES projects are not big enough to encourage the usage of RES technologies, and they are not always making farms much more energy self-sufficient or energy independent [102]. The potential high requirement for planning permission of RES technologies and the lack of renewable energy optimization in planning possibilities are other important regulatory barriers [103].

At the same time, there are motives of RES penetration under the same socio-political, regulatory, and environmental cluster. High-energy dependency of a country, low poverty level, high-income households, and low energy prices are important motives for RES installation. Long-term stable state policies that support low-carbon transition in all sectors and active involvement and participation of community members in the planning and implementation of low-carbon energy transition policies create motives for renewable energy initiatives in rural communities [104]. The high independence of regional governments and strong political support of the renewable energy transition, including strong energy citizenship movement among community members, are strong motives of RES initiatives [105]. Historically, the well-established cooperative movement in rural communities has a positive impact on evolving community's RES initiatives and clustering as well as collective presumption. As renewable energy projects help reduce pollution and improve the environment and health of rural communities, sometimes, it can be a significant motive for rural communities to engage in RES initiatives. In addition, RES projects allow protecting rural communities from higher energy costs in the future and can make farms more energy self-sufficient. Moreover, RES projects allow protecting farms from possible power cuts and energy supply disruptions [105,106].

The behavioral and psychological barriers to the adoption of RES technologies are linked to the worries about their quality and complexity as well as the absence of awareness about the advantages of renewable energy sources [107]. The supposed intricacy of renewable microgeneration technologies has a negative influence on the willingness to adopt these technologies [108]. Moreover, the fears about the efficiency and safety of these 
technologies may lower the attentiveness in implementing renewable energy technologies. There have been privacy and data security concerns that are relevant to the smart grids, as the interactive nature of these installations requires the collection and utilization of extensive datasets. Hence, the lack of knowledge on the major benefits and pitfalls related to renewable energy technologies (this can be especially pronounced in the rural communities) renders lower possibilities to know about the recent innovations and technological progress in this field [109]. Furthermore, the optimal renewable energy system needs few important elements: smart meters, RES generation system, energy monitoring, Internet connection, business agreement under a specific business model with energy companies, etc. $[110,111]$. However, there are no turnkey solutions for renewable energy technologies, and this as well enlarges the difficulty of attaining renewable energy technologies [112].

There are several behavioral and psychological motives behind the adoption of RES technology in rural communities. RES projects allow using innovative and high-tech systems that have an impact on the know-how and capacity development of rural communities [113]. Continuous training, which is necessary for the use of RES technologies, would increase the human capital in rural communities. Positive attitudes of rural community members and farmers towards the cooperative models are important motives to be engaged in RES community initiatives [114]. Moreover, sometimes, farmers would like to show their environmental commitment to other community members [115].

In Table 1, the barriers and motives of renewable energy initiatives in rural areas are systematized.

Table 1. Barriers and motives of renewable energy initiatives in rural areas.

\begin{tabular}{|c|c|c|}
\hline Type of Barrier or Motive & Motives & Barriers \\
\hline \multirow{7}{*}{ Financial or economic cluster } & $\begin{array}{l}\text { Money savings or additional incomes from lower } \\
\text { fuel bills and governmental support measures. }\end{array}$ & $\begin{array}{l}\text { The investment costs are becoming a minor barrier, as } \\
\text { currently RES, especially photovoltaic as well as small } \\
\text { hydroelectricity projects and small-scale wind generators, } \\
\text { are becoming increasingly competitive in most European } \\
\text { countries, and indeed, in most of the world. }\end{array}$ \\
\hline & An increase in the value of the farm and home. & Earning and money savings are limited. \\
\hline & $\begin{array}{l}\text { Additional income for prosumers from the } \\
\text { energy sales. }\end{array}$ & Loss of all investments when moving out. \\
\hline & $\begin{array}{l}\text { Additional income from land leasing for the } \\
\text { installation of large solar or wind parks, etc. }\end{array}$ & $\begin{array}{l}\text { Quite high costs of renewable energy technology } \\
\text { maintenance; however, these costs are dramatically } \\
\text { diminishing with the rise of solar and wind power } \\
\text { generation as viable commercial options. }\end{array}$ \\
\hline & $\begin{array}{l}\text { Switching from fossil fuels to renewable energy } \\
\text { sources lowers the costs of agricultural production } \\
\text { due to the high prices of fossil fuels. }\end{array}$ & Unknown operational costs. \\
\hline & $\begin{array}{l}\text { The use of organic waste from agricultural } \\
\text { production and animal waste for energy } \\
\text { generation allows obtaining economic benefits. }\end{array}$ & $\begin{array}{l}\text { Lengthy investment payback, which is as well constantly } \\
\text { diminishing with the decreasing costs of RES projects. }\end{array}$ \\
\hline & High energy dependency of the country. & $\begin{array}{l}\text { There are still many regulations that protect big fossil } \\
\text { energy producers from free competition due to their high } \\
\text { lobbying power, and currently, this is one of the most } \\
\text { important barriers to the fast penetration of RES. }\end{array}$ \\
\hline \multirow{4}{*}{$\begin{array}{l}\text { Socio-political, regulatory, } \\
\text { and environmental cluster }\end{array}$} & $\begin{array}{l}\text { Low poverty level, high income of households, } \\
\text { and low energy prices. }\end{array}$ & $\begin{array}{l}\text { Lack of attention from local authorities and no resources } \\
\text { are allocated for the engagement in RES promotion } \\
\text { programs or community RES initiatives. }\end{array}$ \\
\hline & $\begin{array}{l}\text { Long-term stable state policies that are supporting } \\
\text { the low-carbon transition in all sectors. }\end{array}$ & $\begin{array}{l}\text { Low income and high electricity prices; high poverty and } \\
\text { inequality in the country. }\end{array}$ \\
\hline & $\begin{array}{l}\text { Active involvement and participation of community } \\
\text { members in the planning and implementation of } \\
\text { low-carbon energy transition policies. }\end{array}$ & $\begin{array}{l}\text { Unstable political support and changing policies to } \\
\text { promote the use of renewables and low-carbon transition of } \\
\text { the energy sector, unsure subsidies and changing policies. }\end{array}$ \\
\hline & $\begin{array}{l}\text { Energy activism traditions and collaborative } \\
\text { political cultures. }\end{array}$ & $\begin{array}{l}\text { Insufficient local community engagement } \\
\text { and participation. }\end{array}$ \\
\hline
\end{tabular}


Table 1. Cont.

\begin{tabular}{lll}
\hline Type of Barrier or Motive & Motives & Barrier
\end{tabular}

High independence of regional governments.

Low capabilities of community leaders to preserve the interest and participation of community members in daily work that is related to the RES technologies licensing, financing, and management.

Strong political support of renewable energy transition.

Strong energy citizenship movement among the community members.

Historically well-established cooperative movement in rural communities is having an impact on evolving the community RES initiatives and clustering as well as collective prosumption.

Renewable energy projects help to reduce pollution and improve the environment and health of the rural communities

RES projects allow protecting rural communities from higher energy costs in the future.

RES projects can make farms more energy self-sufficient.

RES projects allow protecting farms from possible power cuts and energy supply disruptions.
Regional government is dependent.

Lack of incentives and unclear, underdeveloped business models to support prosumption.

Lack of openness from the vendors of technologies, which has a negative impact on the participation of the end users in RES technology testing and the provision of feedback

Prevalence of Not In My Back Yard (NYMBY) phenomenon in local communities when communities are resisting RES projects that are implemented in the nearby area, regardless its positive or negative impacts.

The environmental benefits are not big enough to encourage the usage of RES technologies.

RES projects are not always making farms much more energy self-sufficient or energy independent.

Potentially high requirements for planning permissions of RES technologies.

Lack of renewable energy optimization in the planning possibilities.

Ineffectiveness of regional governance due to their high dependence on the national level.

Mandatory regime actors apply various forms of resistance (discursive, material, and institutional) for the RES penetration.

RES projects allow using innovative and high-tech systems that have an impact on the know-how and capacity development of the rural communities.

Continuous training, which is necessary for the use of RES technologies, would increase human capital in rural communities.

Positive attitudes of the rural community members and farmers towards the cooperative models.

Shows environmental commitment of farmers and community members to others.
High uncertainty and lack of trust in renewable energy technologies.

Farm or location is not suitable for "smart solutions", and this creates numerous problems for farmers and community members.

Renewable energy system performance or reliability of these systems is not good enough and causes additional worries for farmers and community members.

In the case of RES technologies, the energy is not available when it is needed due to the high intermittency of energy supply and provides a lot of risks.

For rural communities and farmers, it is hard to find trustworthy information about RES technologies.

For farmers and rural communities, it is hard to find any information, and in the case of disruption or hassle of installation or operations, there are many problems.

Complicated use and maintenance of RES technologies.

Lack of experience and knowledge in rural communities and among the farmers.

The complexity of regional, national, and international funding and subsidy schemes with their various conditions, maturities, exemptions, etc.

Lack of trustworthy information on renewable energy benefits for rural communities. 
Table 1. Cont.

\begin{tabular}{|c|c|c|}
\hline \multirow[t]{6}{*}{ Type of Barrier or Motive } & Motives & Barriers \\
\hline & & $\begin{array}{l}\text { Farmers and community members have a lot of privacy } \\
\text { and security concerns with the data usage in the smart } \\
\text { grids. }\end{array}$ \\
\hline & & Takes up too much space on the farm and is too noisy. \\
\hline & & The installation might damage a home. \\
\hline & & $\begin{array}{l}\text { RES installations may not look good and can damage the } \\
\text { landscape of the farm and community land. }\end{array}$ \\
\hline & & RES installation might cause the neighbor's disapproval. \\
\hline
\end{tabular}

Source: created by the authors, based on [21-24,95-115].

The possible factors that have been outlined in Table 1 suggest the presence of multiple key barriers and motives for partaking in the prosumerism and renewable energy technology adoption among rural citizens. It should be stressed that the importance of some barriers, such as the financial one, is constantly decreasing due to the growing competitiveness of renewable technologies, especially solar and wind, which are very relevant in the rural territories. The main barriers are regulatory, as regulations that are sheltering big fossil energy producers from the free competition are still available in many countries due to the strong lobbying power of big fossil producers.

Addressing the main barriers identified in Table 1 and exploiting the benefits of RES are important tasks for achieving effective policy measures. These are discussed in the next section.

\section{Policies to Overcome Barriers of Renewable Energy Initiatives in Rural Areas}

The current trends in energy sector development, especially in highly developed states, show that the energy systems are becoming more and more open, adaptable, and environmentally sustainable, and new actors and new business models are emerging [116]. This energy sector transition to carbon-free energy generation sources is rather complex and requires more opportunities and support of new operation modes to emerge and develop sustainably [117]. The transition towards the sustainability of the energy system requires state support on the macro and micro levels, and the creation of niche markets is necessary to facilitate the changes of the energy regime. The energy prosumers can be treated as important actors in emerging niches [118]. Thus, the policy support is a critical accelerator of a low-carbon energy transition and the creation of a carbon-neutral society, as established in the EU Green Deal agreement. Therefore, governments have established policies and measures to encourage the adoption of sustainable solutions in the energy sector that are, first of all, linked with the fast penetration of renewable energy sources and abandoning fossil fuels. However, recent studies have shown that the policy incentives are not sufficient to ensure a successful low-carbon energy transition. There are several groups of policies and measures targeting social, economic, technological, informational, behavioral, etc., barriers of low-carbon energy transition and penetration of RES, especially in the rural areas $[119,120]$.

Some authors suggest a division of policies and measures to economic and noneconomic policies and measures (Kotilainen, Saari, 2018) [44]. The economic instruments rely on market power and require minimal interventions after the setup. The non-economic instruments mostly rely on institutional arrangements.

The economic instruments are very important in the promotion of renewable energy sources, as they can be effective in promoting the desired activities of individuals. These instruments are very productive in strengthening the market-based drivers of renewable energy and climate change mitigation actions [121]. The economic instruments are also useful to deter unwanted activities, such as environmental pollution or the generation of waste by imposing taxes on pollution. Examples of economic policies and measures that have a positive influence on GHG emission reduction and the promotion of renewables are 
GHG emission trading schemes, GHG taxes, tax credits and discounts, public investments and funding, subsidies, and loan guarantees [98,122,123].

The non-economic instruments can be grouped into two types. First, the commandand-control instruments are legally binding and are applied to imitate the otherwise missing market signals, leading to the desirable innovations. Examples of such measures include capping GHG emission, standardization, feed-in quotas, and tradable green and white certificates $[44,124]$. These instruments aim to enforce sanctions in case of policy violations. Command-and-control instruments can be useful in directing the desired outcomes; however, these instruments require many resources [44]. Though the regulations are targeting all actors, in reality, smaller market actors (such as individual prosumers) that have fewer resources and less capacity to combat bureaucracy will not be able to take advantage of these instruments. Secondly, the soft instruments are represented by nonbinding measures such as public awareness campaigns, environmental and ethical labeling, and various voluntary instruments, including voluntary environmental agreements, corporate social responsibility initiatives, etc. [44,125-128]. As a soft instrument, the awareness campaigns can be considered particularly beneficial in shifting the public opinion towards the acceptance of new renewable energy technologies [129]. The information dissemination tools and tools for building environmental awareness work well to ensure the diffusion of renewable energy technologies [130,131].

The command-and-control policies, such as EU directives, are imposed on the macrolevel. There are macro-level policies and measures that regulate the possibilities of distributed generation and microgeneration on the country and municipality level, which are very important for renewable energy initiatives in rural communities [132]. Commandand-control policies and measures are established to influence the advance of energy systems from the top-down, whereas soft instruments that are based on voluntary and self-regulation approaches can stem from the grassroots [101].

However, the economic and non-economic instruments are not always able to support renewable energy initiatives. There are several theories allowing to deal with the behavioral barriers of penetration of renewable energy technologies, i.e., theory of diffusion of innovation (DOI) or innovation diffusion theory (IDT), proposed by Rogers [133]. For new technology adoption in the persuasion phase, the most important factor is a relative advantage. It signifies the net benefits (economic, environmental, etc.) of new technologies. It is obvious that the perceived costs of new technology acceptance will have a negative impact on the relative advantage factor. The costs of new technologies encompass financial costs and implicit costs that are related to the uncertainty surrounding new technologies (risks, considerations over operation, privacy concerns) [134].

The main benefits linked to renewable energy technologies encompass economic benefits, such as energy costs savings, trophy value, higher energy consumption awareness, etc. The economic benefits of renewable energy technologies usually require time to be materialized and, therefore, decrease the interest in adopting renewable energy technologies [135]. The environmental benefits of renewable energy technologies have a positive impact on the relative advantage, and the environmental reasons were found to be the main arguments for introducing smart metering technology [136]. The compatibility factor describes how well a new technology suits the present way of living of the energy consumer. If the adoption of renewable energy technology requires behavioral changes, the interest, especially of late adopters, will decrease significantly [133]. The most important motivator of behavioral changes is the price, and the economic policies and measures are often targeting the price signals [137]. The complexity of renewable energy technology has a negative impact on technology adoption, as complex technologies and products usually have longer diffusion times than products that are easy to use [138]. The research shows [138] that the early adopters are usually not worrying about the complexity of new technologies that much. The trialability factor is linked to the possibility of the customer trying out new technology in a risk-free situation without facing significant costs. The accessibility of leasing will increase the willingness to adopt new technologies. The trialability is crucial 
for early adopters, which usually are fascinated to try new technologies and give advice and feedback to the developers of new technologies [138]. The observability factor is more essential for the late adopters of new technologies, as they rely on the recommendations of early adopters $[44,138]$.

Traditional economic theories postulate consumers' rationally, as they try to optimize their welfare with limited resources. However, behavioral economics proved that the rational approach is the oversimplification of customer decision-making [139]. The complexity of the consumer decision-making process is described in many references. The motivation of prosumption has been addressed in several studies as well. Balcombe et al. [36] analyzed the process of microgeneration technology adoption and systematized the main motivation factors. These main factors of technology adoption are the following: financial resources, environment, security of energy supply, uncertainty and trust, inconvenience, and impact on the residence.

There are intrinsic and extrinsic motivations for the adoption of new technologies [140]. There are several theories providing answers for consumer decision-making in adopting new energy technologies: the Value-Belief-Norm (VBN) theory [141], Theory of Reasoned Action (TRA) developed by Fishbein and Ajzen [142], and Theory of Planned Behavior (TPB) developed by Ajzen [143]. The TRA and TPB models are key in analyzing the pro-environmental and climate change mitigation behavior of individuals. These theories relate beliefs, attitudes, perceptions, and subjective norms to individual intentions that can be used to predict an individual's actual behavior. The technology acceptance model (TAM) $[44,144]$ was developed based on these theories. The TAM and its various modifications have the same theoretical background: the perceived usefulness and the ease of practice with new technologies provide positive attitudes regarding the use of innovative technology, and the intentions to exploit a novel technology can be predicted based on these attitudes. Davis [144] has introduced the TAM model that has six main elements of new technology acceptance: external factors, perceived ease of use, perceived usefulness, attitude toward using, behavioral intention to use, and the actual use of new technology.

The perceived ease of using new technology has a positive impact on the perceived usefulness and the attitude towards the use of new technology. At the same time, the perceived usefulness also has a positive impact on the behavioral intention to use new technology, which ultimately affects the factual usage of new technology.

The TAM model is similar to the IDT model, and both of these models have been broadly used for modeling new technology acceptance. TAM is very widely applied in studies that are dealing with sustainable energy issues [44]. Venkatesh et al. [145] have developed TAM further by integrating factors of social influence, etc. Several studies have also highlighted the gaps between attitudes, intentions, and behaviors linked to the new technology adoption [44]; however, these technology acceptance models are very useful in the analysis of climate change mitigation policies and measures and their effectiveness in supporting the fast penetration of renewable energy technologies.

There are policies and measures that inherently support certain community activities, but not necessarily other arrangements. However, there are ethical problems of renewable energy community initiatives that are linked to the probabilities of free-riding, contests for democracy and equity [124]. It is necessary to stress that there are no policies and measures that can concurrently promote all forms of renewable energy community initiatives. There are always policies and measures as rules and standards, tax reductions, various financial support instruments, which will favor a specific community more instead of another community [64,146]. As there are diverse community types and various renewable energy community initiatives, it is possible to state that various types of communities have different institutional, organizational, and ownership contexts. The main types of energy communities are place-based and non-place-based, single-purpose and multi-purpose energy communities.

The policies and measures have different impacts on the initiatives of place-based and non-place-based energy communities. The policies and measures that are similar to direct 
subsidies and grants, property tax rebates, and indirect financial assistance tools, such as loan guarantees or low-interest loans, are more preferential to the dispersed ownership forms of small RES plants. In general, the policies and measures that are supporting renewable energy community initiatives favor place-based communities more. The same applies to the policies and measures that have been established to facilitate the development of smart microgrids [147].

Therefore, the policies and measures that are targeting renewable energy community initiatives favor place-based communities more than non-place-based communities. The policy tools that have been created to favor new forms of local engagement $[60,148]$ and the establishment of local public-private partnerships apply mainly to the place-based energy communities. It is necessary to note that local engagement and participation are especially important for a particular place, as it aims to address its specific difficulties. The same is relevant for the establishment of public-private partnership initiatives, which are usually linked to the public and private actors in the local area.

Place-based communities are more popular, as it is easy to establish such a community. They have a self-governing structure that enables the acceptance of new RES technologies [60]; however, self-governance may hamper the adoption of renewable energy technologies as well. For example, in the case of homeowners associations, there are many more organizational problems that are related to the adoption of renewable energy technologies, compared with the individual household situation agreement that needs to be achieved among the members.

It is necessary to distinguish between single-purpose and multi-purpose communities for decision makers that are seeking to increase the role of communities in low-carbon energy evolution. The policies and measures, which deliver a greater space to communities in all possible activities and sectors, have a positive impact on the penetration of renewable energy technologies and boosting renewable energy community initiatives. Some policies support communities for achieving specific goals, such as climate change mitigation and penetration of renewables; other policies target inherent goodness of communities, such as citizenship or other advanced organizational forms of civil society. The policies and measures that are concentrating on single-purpose communities are, for example, tax rebates that support specific ways of energy production. The policies and measures that are aiming to support multi-purpose energy communities are, for example, tax rebates or allowances for any type of community initiative or action [60]. In the first case, the tax rebate will promote an outcome; in the latter, it targets a self-organized form of management, which can be more encouraging in a specific community [148]. It is necessary to stress that diverse communities have varied organizational and ownership outlines and policies and measures that aim to promote renewable energy; thus, community initiatives should consider this in order to be successful.

In Table 2, the policies and measures for eradicating the barriers of renewable energy initiatives in rural areas and their links to the main technology adoption theories are summarized. All barriers to the adoption of renewable energy technologies or renewable energy community initiatives were related to the theory (TAM and IDT), and further on, they were linked to the specific policies and types of measures.

As one can see from Table 2, the main barriers are related to the perceived usefulness and the perceived ease of the use of new technologies based on TAM. The barriers are also linked to specific IDT elements. According to TAM, the length of the investment payback period is associated with the perceived usefulness, as it trades off the renewable energy technology benefits as perceived by the possible adopter of new technology [146]. Moreover, the length of the payback period is linked to the relative advantage, as it is the main measure of cost-benefit analysis of renewable energy technologies. Thus, the policies and measures that are aimed to address the specific barriers were categorized as economic and non-economic policies (regulatory and soft policies). 
Table 2. Policies and measures to overcome renewable energy initiatives in rural areas and their linkages with the main technology adoption theories.

\begin{tabular}{lcccc}
\hline $\begin{array}{l}\text { Barrier of Renewable Energy } \\
\text { Community Initiatives }\end{array}$ & TAM & IDT & Policies & Policies and Measures \\
\hline
\end{tabular}

Investment costs and long payback period of investments are becoming less important due to the reduction in RES installation costs
Perceived usefulness Relative advantage Economic Unknown operational costs $\quad$ Perceived usefulness $\quad$ Relative advantage $\quad \begin{aligned} & \text { Economic and } \\ & \text { non-economic }\end{aligned}$

State's financial support in the form of subsidies, grants, loan guarantees, lowinterest loans, tax rebates and exemptions, GHG and other pollution taxes, GHG emission trading, etc., the establishment of financial support institutions

Tax rebates and exemptions, GHG emission taxes and GHG emission trading, feed-in-tariffs and quotas, incentive schemes, green tradable certificate schemes, information dissemination campaigns

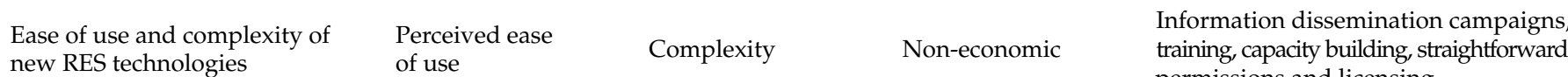

$\begin{array}{lll}\text { new RES technologies of use permissions and licensing } & \end{array}$

\begin{tabular}{lllll}
\hline $\begin{array}{l}\text { Renewable energy benefits are } \\
\text { not fully comprehended }\end{array}$ & Perceived usefulness & Relative advantage & Non-economic & $\begin{array}{l}\text { Information dissemination campaigns, } \\
\text { education, training, and capacity building }\end{array}$ \\
\hline $\begin{array}{l}\text { No interest in new } \\
\text { RES technologies }\end{array}$ & Perceived usefulness & Compatibility & Non-economic & $\begin{array}{l}\text { Information dissemination and } \\
\text { environmental awareness-raising } \\
\text { campaigns, education, capacity } \\
\text { building and training }\end{array}$ \\
\hline
\end{tabular}
building and training

Information dissemination and education campaigns, training, Concerns about the data security Perceived usefulness Relative advantage Non-economic capacity building, the establishment of data privacy and protection laws and regulations, secure management of all sensitive data

Support of commercialization, information dissemination campaigns, education and capacity building

The abolishment of regulations that shelter big fossil fuel producers and the establishment of a competitive position of RES technologies in the energy markets

Improvement of legislation, creation of favorable conditions to prosumers, including collective prosumers, such as energy cooperatives and regulation quality, eradicating bureaucracy, the establishment of supporting institutions and middle players in the RES markets

Decentralization of governance structure and strategic planning, state support of community engagement

Low cooperation culture, low community participation and engagement $\begin{array}{ll}\text { Perceive usefulness Complexity } & \begin{array}{l}\text { Non-economic } \\ \text { and economic }\end{array}\end{array}$ and participation, promotion of social coherence, advancement of energy citizenship and other democratic forms of community involvement

The economic policies and measures are mainly financial subsidies and grants, loan guarantees, soft loans, and loan guarantees as well tax rebates and regulatory policy improvements, containing rules and regulations or the reduction in bureaucracy. The vested interests and lobbying power of big fossil fuel utilities are one of the obstacles to the implementation of RES, if not the main; therefore, the regulations that protect big fossil fuel utilities from fair competition should be abolished, including the removal of 
environmentally harmful subsidies for fossil fuels. It is necessary to stress that the financial costs, including operational costs, are not a significant barrier to RES since PV and wind energy is especially competitive in most European countries already. The primary focus should be paid to the regulatory barriers that are distorting free competition in the energy markets.

The soft measures include information dissemination campaigns, education, and capacity-building measures. The soft measures also include political support of community engagement and participation, promotion of social coherence, and advancement of energy citizenship and other democratic forms of community involvement. These policies and measures can be linked to the perceived usefulness, according to the TAM model, and the relative advantage and complexity, according to the IDT model. The barrier of a lengthy investment payback period can be overcome by applying economic policies.

However, the results of the literature review revealed that though there are similar policies and measures implemented to overcome the renewable energy penetration barriers in rural areas, the effect of these policies differs among the rural communities. Therefore, there are important success factors of renewable energy initiatives in rural communities that have been defined in several studies [106].

As rural community projects are usually minor and mostly depend on the motivation and capacities of the members of communities or cooperatives. A number of individual characteristics, such as environmental awareness, management and engineering skills, leadership, entrepreneurship, knowledge and expertise, adaptive capacity, access to technology, etc., have a positive impact on the successful development of renewable energy initiatives in specific rural areas. There are as well other important success factors of renewable energy initiatives in the rural areas. Middlemiss and Parrish [100] differentiate the important factors for the success of renewable energy initiatives in rural areas: cultural, organizational, infrastructural, and personal capacities of energy community members. All these relevant capacities can be grouped into strategic, institutional, and physical dimensions of the success of renewable energy initiatives in rural communities.

The cultural capacity, under the strategic dimension of the success of RES community initiatives, covers the legitimacy and socially outlined importance of sustainability goals as well as how deep they are embedded in the rural community values. The cultural capacity reveals the environmental attitudes and the intrinsic impetus to perform according to the environmental/sustainability criteria [104]. Due to the cultural values, people in some societies are inherently motivated to work for the improvement of the surrounding environment, meaning that even economically unworkable projects will be implemented as well. However, the economic interests are very important drivers of renewable energy initiatives, as financial and economic barriers are the main obstacles for implementing the RES projects. The individual motivations of community members for the engagement in RES initiatives are very different, and at the same time, they are supplementing each other.

The social activities in initiating local RES projects can be linked to autarky, anticapitalism, security of energy supply, and anti-nuclear attitudes of rural communities [106]. Such motives can act together with environmental and economic motivations due to the growth of economic profitability of RES projects that are linked to fast technological developments and innovations in RES technologies. The subsidy schemes and other external support as well contribute to the attractiveness of local RES initiatives. Local renewable energy initiatives stipulate an increase in the security of energy supply and energy self-sufficiency of community members, empower to control energy production and supplies, and reduce the risk of energy supply disruptions in rural communities.

Another important strategic dimension of the success of renewable energy initiatives in rural communities is the organizational capacity of a rural community. It indicates the position of community renewable energy initiatives in the wider rural community. Usually, the renewable energy projects in rural communities are supported due to their positive impact on self-sufficiency, an increase in the local engagement and participation, social cohesion and enabling of rural communities [99]. It is obvious that social support of a 
wider rural community for renewable energy initiatives indicates a positive transition to energy citizenship, strengthens social cohesion of rural communities, and has a positive impact on the success of these projects [104]. Successful involvement of the rural community in RES projects constructs wisdom of ownership and responsibility of community members for the RES initiative by mitigating Not in My Back Yard (NIMBY) effects, as the NYMBY phenomenon has a negative impact on the local acceptance of wind parks, solar panels, hydropower plants, etc. $[105,114]$. Thus, the rural communities need social capital and social cohesion as well as political in order to be able to establish renewable energy initiatives [105]. Another strategic success dimension of renewable energy community projects is the infrastructural capacity that is linked to the access to the grid, infrastructure, and other facilities that are necessary for RES projects. Rural communities are able to test new RES technologies by promoting innovation and local development [117].

Moreover, personal capacity is an important strategic capacity that is necessary for the success of RES initiatives in rural communities. The personal capacity indicates the capacities of individual members of RES initiatives. Therefore, it is obvious that community RES initiatives are dependent on the voluntary inputs, inherent motivations, and capacities in the collective actions of individual members of the rural community. The main personal capacities that are necessary for the success of RES initiatives cover knowledge and expertise, various management or technological skills, leadership and entrepreneurship, enthusiasm, and resistance [100]. The knowledge and expertise, access to technology, available financial resources are very important for the success of RES projects in rural communities [117]. These different capacities reveal the strength and provide for the success of the local community's RES projects.

The literature on renewable energy initiatives distinguishes multiple institutional circumstances that occur at the macro or meso levels and empower or restrain RES initiatives in the rural communities. These important factors determine the institutional space of local community initiatives and are important drivers for successful renewable energy initiatives. The studies [106,116] argue that innovations need space, which can be established by the interactions between physical, socio-cultural, economic, political, regulatory, and legal subsystems.

The political capacity, under institutional success factors, includes state support for RES in subsidies, soft loans, tax rebates, continuous policies to support RES, priorities in implementing sustainability goals, project support services, including advice and access to funding, networking, etc. All these political capacities have a significant impact on the success of RES initiatives in rural areas. Note that the political factors can be explicit (e.g., legal framework) and implicit (e.g., soft traits related to the motivation to embark on the RES-related projects).

The legal success dimension indicates the quality of regulations and rules, the excellence in decision-making, simple and flexible procedures and licensing processes, low bureaucracy, degree of discretionary space, the efficiency of control, and support mechanisms. Therefore, the legal and regulatory conditions are related to the legislation itself as well as the underlying institutional arrangements (decentralization, regional representation, etc.) that may affect the implementation of RES projects.

The economic conditions relate to the allocation of the profit among the stakeholders and the investment-friendliness in a certain region. The profitability of the project is as well playing an important role. It is necessary to note that without access to finances and other resources from other stakeholders, the RES initiatives of rural communities will be very restrained and limited.

The socio-cultural attributes under the institutional dimension contain the public perception of RES. It is closely linked to the perception of the social responsibility that is prevailing in rural communities. Moreover, the rural community's attitudes towards experimenting and innovation are important in general.

The physical dimension of the success of rural RES initiatives provides boundaries for the physical conditions of RES projects in rural communities. The physical boundaries 
include the availability of RES, such as solar irradiation level and biophysical wind potential, potential hydro resources, the available selections for harvesting resources, and access to RES technologies. Furthermore, the spatial planning of rural areas is a vital physical condition. Rural, not urbanized areas, are more suitable for the large RES projects, as the physical space and land for RES projects are less limited and cheaper. Moreover, the remoteness of rural areas causes other obstacles, such as access to the grid and other infrastructure development. Besides that, the spatial layout and degree of urbanization of rural areas have an impact on local structural and agency features. It is necessary to note that the governance structures are less complex in rural areas, and there is less variety of governance scales [116]. Therefore, the success of the RES initiative in the rural area requires that the RES project implementation and planning should be in line with the physical and built environment of the initiated RES project. This requires good quality spatial planning and planning processes [115].

In Table 3, the main success factors of RES initiatives in rural areas are systematized based on the literature review.

Table 3. Success factors of community RES initiatives in rural areas.

\begin{tabular}{|c|c|c|}
\hline Dimension & Capacities & Success Factors \\
\hline \multirow{3}{*}{ Strategical conditions } & Cultural capacities & $\begin{array}{l}\text { The legitimacy of sustainable development goals, environmental } \\
\text { awareness and attitudes, willingness to act in implementing } \\
\text { sustainable development goals that are available in } \\
\text { rural communities }\end{array}$ \\
\hline & Organizational capacities & $\begin{array}{l}\text { Support of state and local authorities and encouragement of local } \\
\text { community renewable energy actions }\end{array}$ \\
\hline & Personal capacities & $\begin{array}{l}\text { Entrepreneurship, visionary leadership, enthusiasm, knowledge } \\
\text { and expertise, access to technology, adaptive capacity, resilience, } \\
\text { management, technical and engineering skills of individual rural } \\
\text { community members }\end{array}$ \\
\hline \multirow[t]{4}{*}{ Institutional conditions } & Political capacities & $\begin{array}{l}\text { Availability and continuity of state and local authorities' incentives, } \\
\text { subsidies, soft loans, tax rebates, etc., priority for sustainable } \\
\text { development goals, state and local authorities' support in terms of } \\
\text { advice and finances for RES projects that are initiated by rural } \\
\text { communities, networking of various stakeholders }\end{array}$ \\
\hline & Legal and regulatory capacities & $\begin{array}{l}\text { Quality of regulations and legislation, sound decision-making } \\
\text { processes, low bureaucratic burden, high degree of discretionary } \\
\text { space, effective control mechanisms }\end{array}$ \\
\hline & Economic capacities & $\begin{array}{l}\text { Proper division of material resources in rural communities, } \\
\text { availability of investors and funds, predictable economic efficiency, } \\
\text { and profitability of RES initiatives }\end{array}$ \\
\hline & Socio-cultural capacities & $\begin{array}{l}\text { Availability of high capacity for institutional learning and problem } \\
\text { perception, positive attitudes on the experimentation in rural } \\
\text { communities }\end{array}$ \\
\hline Physical conditions & & $\begin{array}{l}\text { Potentially high average wind speed, high solar irradiation level, } \\
\text { availability of tidal waves, high hydropower resources, high } \\
\text { biomass potential, availability of vast land areas, which can be used } \\
\text { for RES projects, presence of fossil fuels, urbanization level of } \\
\text { territory, technological development level of RES technologies that } \\
\text { are available }\end{array}$ \\
\hline
\end{tabular}

Source: created by the authors, based on [100-106,114-117].

As one can see from Table 3, the success factors of RES initiatives in rural communities are linked to strategic, institutional, and physical conditions of the country and municipality. 
The review of the main barriers and motives of renewable energy penetration in rural areas revealed that the main barriers are currently socio-political and regulatory (Figure 2).

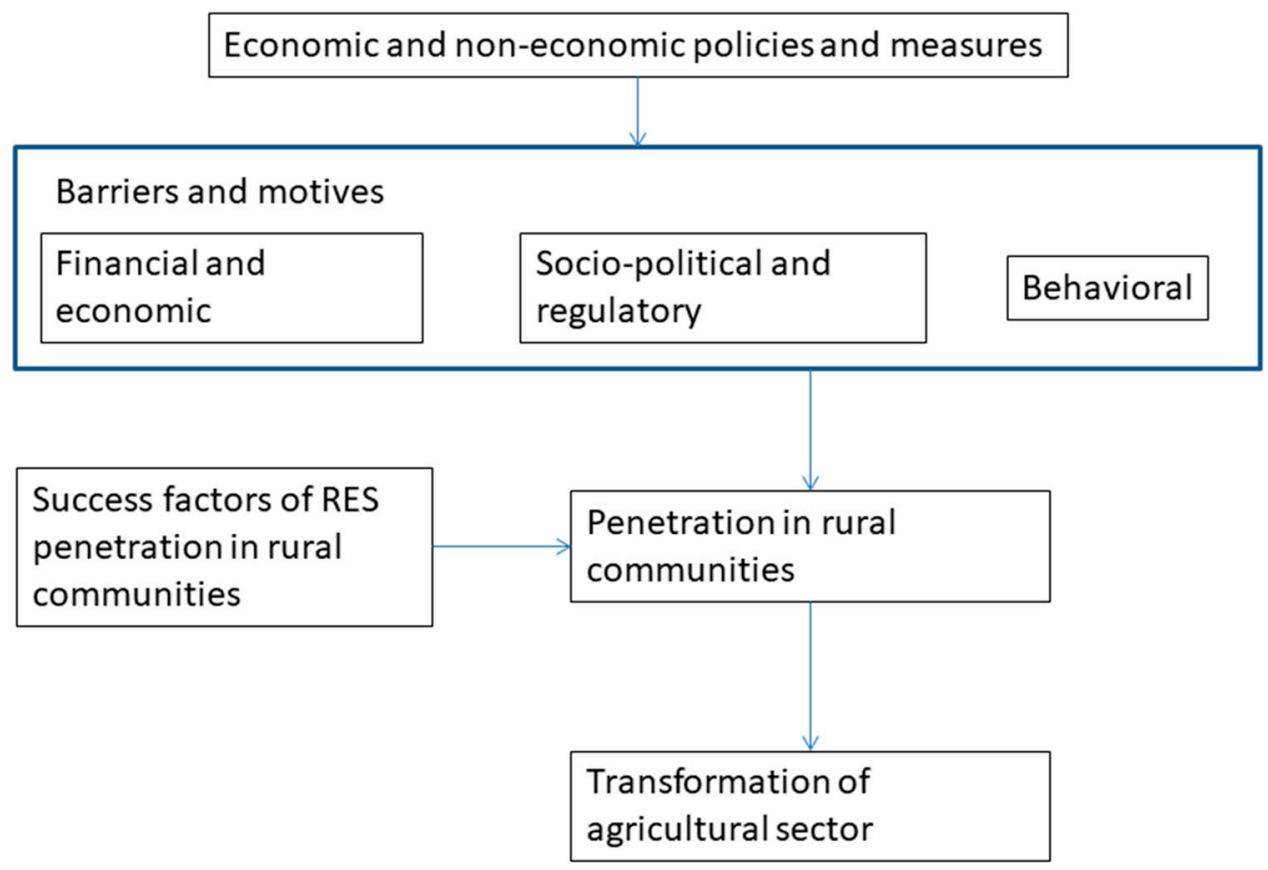

Figure 2. The main drivers and motives of renewable energy penetration in rural areas. Source: created by the authors.

The importance of economic barriers is diminishing with an increase in the competitiveness of renewables. The policies and measures that have been developed to address the main barriers of renewable energy penetration are linked to the non-economic policies due to the decreased importance of financial and economic barriers. Moreover, strategic, institutional, and physical conditions and success factors are very important for the success of renewable energy initiatives in rural communities. Therefore, the effectiveness of policies and measures that are promoting renewable energy sources and overcoming major barriers depends on the local situation and various capacities of local rural community members. As one can see from Figure 2, the penetration of renewable energy sources in rural communities, in the end, allows achieving the transformation of agri-food systems as described in Section 3.

\section{Conclusions and Policy Implications}

There are several important barriers that are inhibiting renewable energy initiatives in rural areas. However, in some countries, the policies and measures to overcome these barriers are more successful than in other countries. This happens because of the different strategic, institutional, and physical conditions that are available in different countries and the effect of the implemented policies that are targeting RES community initiatives that depend on these conditions as well.

The institutional (political, legal, economic, and social-cultural conditions) are very important for the success of community renewable energy initiatives. In rural communities, the institutional dimension is especially important for the success of renewable energy initiatives, as the central discourse across the governance levels and actors has an impact on all local initiatives. If the rural community has a political motivation that is similar to the governmental institutions, this provides many openings for rural community renewable energy initiatives.

The analysis that has been performed revealed that the strategic dimension of the success of renewable energy community initiatives covers cultural, organizational, and 
personal capacities, which are different in different locations. Physical characteristics are very important as well. Although there are different national institutional arrangements for the community's renewable energy initiatives, the agency features, such as entrepreneurship and leadership skills, environmental awareness, and other skills, play a vital role. The prospects to develop renewable energy projects and planning processes depend on the physical conditions, such as the availability of potential renewable energy resources in the community area, as well as the degree of urbanization. Currently, most renewable energy projects and prosumption activities are realized in urban areas; however, rural regions are also facing an increasing variety of renewable energy projects and energy prosumption options, as new business models are developing very fast. The renewable energy projects that have been initiated by communities became more uniformly dispersed between the urbanized and rural areas. Usually, the state strives to implement large rural and offshore RES projects; however, rural communities started to initiate their own renewable energy projects and establish energy cooperatives. The energy communities and renewable energy cooperatives are the developing forms of renewable energy penetration in rural areas.

Based on the conducted research, this article's authors suggest that decision makers remove regulatory barriers and encourage community members to take part in the energy market actively first. As individuals and communities have different freedom levels to participate in the energy market, the improvement of legislation and regulation will help to overcome this barrier. There are other barriers that are hampering the participation of energy consumers in renewable energy generation, trading and sharing in rural energy communities.

In many countries or geographical regions, RES is increasingly becoming more competitive. The main reason why RES technologies are not implemented faster is because of regulations that shelter big fossil energy producers from free competition that was imposed due to the strong lobbying power of big fossil fuel producers. Therefore, the regulations that protect fossil fuel producers from competition, including environmentally harmful subsidies for fossil fuels, should be abolished.

The policy instruments should support the evolution of consumers to prosumers. There are economic and non-economic policies and measures linked to the regulative processes of connecting RES technologies and soft policies that are promoting the understanding of energy tariffs and RES subsidies and access to information about RES generation.

The energy communities, self-consumption, and prosumer activities should be promoted in line with the European Community directives, such as REDII Directive, etc.

The economic and non-economic policies and measures can be applied to encourage the non-adopters of renewable energy technologies; however, the importance of economic policies is diminishing because RES is becoming increasingly competitive in most European countries and most of the world.

Additionally, the non-economic policies are usually more powerful because of the impact on the behavioral changes of energy consumers. The non-economic policies can change the energy consumer's attitudes towards using RES technologies, as technology adoption theories advocate. The various packages of policies and measures covering economic and non-economic instruments are necessary in order to address all barriers of renewable energy initiatives in rural communities.

Moreover, the security of data is essential for energy consumers. The smart grids are based on ICT and use a big quantity of private data about energy consumption and production. The well-managed data can help to facilitate the acceptance of new RES technologies, as energy consumers value the capacity to monitor and regulate their energy consumption.

There is a huge distinction between the attitudes of RES technology adopters and non-adopters due to the different personal characteristics of early adopters and late new technology adopters [88-90]. The initial policies and measures are designed to encourage the penetration of renewable energy technologies and no longer encourage early adopters. 
Thus, diverse policies and measures are necessary to encourage the initial acceptance of renewable energy technologies and continuous prosumption, taking into account the personal characteristics in terms of new technology adoption. The phasing out of certain policies and measures is advisable when the diffusion of RES technologies has already been started. Therefore, though stability in policy and regulatory regimes is advisable, the stages of renewable energy technology adoption and market segments should be distinguished by the policymakers.

Author Contributions: Conceptualization, D.S. and T.B.; methodology, A.V. and M.M.; investigation, D.S. and T.B.; formal analysis, A.Z. and A.V.; resources, D.S.; writing-original draft preparation, D.S. and T.B.; writing-review and editing, D.S. and A.V.; visualization, J.S.; validation, J.S.; supervision, D.S. and M.M. All authors have read and agreed to the published version of the manuscript.

Funding: This research was funded by a grant (No. P-MIP-21-201) from the Research Council of Lithuania.

Institutional Review Board Statement: Not applicable.

Informed Consent Statement: Not applicable.

Data Availability Statement: Not applicable.

Conflicts of Interest: The authors declare no conflict of interest.

\section{References}

1. Ryghaug, M.; Skjølsvold, T.M.; Heidenreich, S. Creating energy citizenship through material participation. Soc. Stud. Sci. 2018, 48, 283-303. [CrossRef] [PubMed]

2. Devine-Wright, P. Energy citizenship: Psychological aspects of evolution in sustainable energy technologies. In Governing Technology for Sustainability; Routledge: Milton Park, UK, 2007; pp. 74-97.

3. Radtke, J.; Holstenkamp, L.; Barnes, J.; Renn, O. Concepts, formats, and methods of participation: Theory and practice. In Handbuch Energiewende und Partizipation; Springer VS: Wiesbaden, Germany, 2018; pp. 21-42.

4. Lowitzsch, J.; Hoicka, C.E.; van Tulder, F.J. Renewable Energy Communities under the 2019 European Clean Energy PackageGovernance Model for the Energy Clusters of the Future? Renew. Sustain. Energy Rev. 2020, 122, 109489.

5. Wagemans, D.; Scholl, C.; Vasseur, V. Facilitating the Energy Transition-The Governance Role of Local Renewable Energy Cooperatives. Energies 2019, 12, 4171. [CrossRef]

6. Haf, S.; Robison, R. How Local Authorities Can Encourage Citizen Participation in Energy Transitions; Energy Research Centre: London, UK, 2020.

7. Mickey Lauria, M.; Slotterback, S.C. (Eds). Learning from Arnstein's Ladder. From Citizen Participation to Public Engagement; Routledge, Taylor \& Francis Group: Milton Park, UK, 2021; 362p.

8. Collins, K.; Raymond, I. Dare we jump off Arnstein's ladder? Social Learning as a New Policy Paradigm. In Proceedings of the PATH (Participatory Approaches in Science \& Technology) Conference, Edinburgh, Scotland, 4-7 June 2006.

9. Cardullo, P.; Kitchin, R. Being a 'citizen' in the smart city: Up and down the scaffold of smart citizen participation in Dublin, Ireland. GeoJournal 2019, 84, 1-13. [CrossRef]

10. Dóci, G.; Vasileiadou, E.; Petersen, A.C. Exploring the transition potential of renewable energy communities. Futures 2015, 66, 85-95. [CrossRef]

11. Jenkins, K.; McCauley, D.; Heffron, R.; Stephan, H.; Rehner, R. Energy justice: A conceptual review. Energy Res. Soc. Sci. 2016, 11, 174-182. [CrossRef]

12. Sovacool, B.K.; Burke, M.; Baker, L.; Kotikalapudi, C.K.; Wlokas, H. New frontiers and conceptual frameworks for energy justice. Energy Policy 2017, 105, 677-691. [CrossRef]

13. Delina, L.L.; Sovacool, B.K. Of temporality and plurality: An epistemic and governance agenda for accelerating just transitions for energy access and sustainable development. Curr. Opin. Environ. Sustain. 2018, 34, 1-6. [CrossRef]

14. Blue, G.; Rosol, M.; Fast, V. Justice as Parity of Participation: Enhancing Arnstein's Ladder Through Fraser's Justice Framework. J. Am. Plan. Assoc. 2019, 85, 363-376. [CrossRef]

15. Lennon, B.; Dunphy, N.P.; Sanvicente, E. Community acceptability and the energy transition: A citizens' perspective. Energy Sustain. Soc. 2019, 9, 35. [CrossRef]

16. McCauley, D.; Ramasar, V.; Heffron, R.J.; Sovacool, B.K.; Mebratu, D.; Mundaca, L. Energy justice in the transition to low carbon energy systems: Exploring key themes in interdisciplinary research. Appl. Energy 2019, 233, 916-921. [CrossRef]

17. Bouzarovski, S.; Simcock, N. Spatializing energy justice. Energy Policy 2017, 107, 640-648. [CrossRef]

18. Sovacool, B.K.; Hook, A.; Martiskainen, M.; Baker, L. The whole systems energy injustice of four European low-carbon transitions. Glob. Environ. Chang. 2019, 58, 101958. [CrossRef] 
19. Sareen, S.; Haarstad, H. Bridging socio-technical and justice aspects of sustainable energy transitions. Appl. Energy 2018, 228, 624-632. [CrossRef]

20. Suboticki, I.; Świątkiewicz-Mośny, M.; Ryghaug, M.; Skjølsvold, T.M. Inclusive Engagement in Energy. 2019. Available online: https:/ / energy-shifts.eu/wp-content/uploads/2019/10/04_Inclusive-Engagement-in-Energy.pdf (accessed on 23 August 2021).

21. Lu, J.; Ren, L.; Yao, S.; Rong, D.; Skare, M.; Streimikis, J. Renewable energy barriers and coping strategies: Evidence from the Baltic States. Sustain. Dev. 2020, 28, 352-367. [CrossRef]

22. Karakaya, E.; Sriwannawit, P. Barriers to the adoption of photovoltaic systems: The state of the art. Renew. Sustain. Energy Rev. 2015, 49, 60-66. [CrossRef]

23. Nasirov, S.; Silva, C.; Agostini, C.A. Investors' perspectives on barriers to the deployment of renewable energy sources in Chile. Energies 2015, 8, 3794-3814. [CrossRef]

24. Painuly, J.P. Barriers to renewable energy penetration; A framework for analysis. Renew. Energy 2001, 24, 73-89. [CrossRef]

25. Hicks, J.; Ison, N. An exploration of the boundaries of 'community' in community renewable energy projects: Navigating between motivations and context. Energy Policy 2018, 113, 523-534. [CrossRef]

26. Piwowar, A.; Dziku'c, M. Development of Renewable Energy Sources in the Context of Threats Resulting from Low-Altitude Emissions in Rural Areas in Poland: A Review. Energies 2019, 12, 3558. [CrossRef]

27. Leenheer, J.; de Nooij, M.; Sheikh, O. Own power: Motives of having electricity without the energy company. Energy Policy 2011, 39, 5621-5629. [CrossRef]

28. Campos, I.; Pontes, L.G.; Marín-González, E.; Gährs, S.; Hall, S.; Holstenkamp, L. Regulatory challenges and opportunities for collective renewable energy prosumers in the EU. Energy Policy 2020, 138, 111212.

29. Balcombe, R.; Rigby, D.; Azapagic, A. Motivations and barriers associated with adopting microgeneration energy technologies in the UK. Renew. Sustain. Energy Rev. 2013, 22, 655-666.

30. Brummer, V. Community energy-benefits and barriers: A comparative literature review of Community Energy in the UK, Germany and the USA, the benefits it provides for society and the barriers it faces. Renew. Sustain. Energy Rev. 2018, 94, 187-196. [CrossRef]

31. Bauwens, T. Explaining the diversity of motivation behind community renewable energy. Energy Policy 2016, 93, 278-290. [CrossRef]

32. Raza, W.; Saula, H.; Islam, S.U.; Ayub, M.; Saleem, M.; Raza, N. Renewable energy resources: Current status and barriers in their adaptation for Pakistan. J. Bioprocess. Chem. Eng. 2015, 3, 1-9.

33. Bardi, U.; El Asmar, T.; Lavacchi, A. Turning electricity into food: The role of renewable energy in the future of agriculture. J. Clean. Prod. 2013, 53, 224-231. [CrossRef]

34. Geels, F.W. The multi-level perspective on sustainability transitions: Responses to seven criticisms. Environ. Innov. Soc. Transit. 2011, 1, 24-40. [CrossRef]

35. Schaaf, T.; Grünig, J.; Schuster, M.R.; Rothenfluh, T.; Orth, A. Methanation of $\mathrm{CO}_{2}$-Storage of renewable energy in a gas distribution system. Energy Sustain. Soc. 2014, 4, 1-14. [CrossRef]

36. Mousazadeh, H.; Keyhani, A.; Mobli, H.; Bardi, U.; Lombardi, G.; El Asmar, T. Environmental assessment of RAMseS multipurpose electric vehicle compared to a conventional combustion engine vehicle. J. Clean. Prod. 2009, 17, 781-790. [CrossRef]

37. El Asmar, T.; Bardi, U.M.; Karlowski, J.M. Renewable energy multipurpose system for farmers (RAMseS)—An environmental, technical and economic assessment with a comparison with a conventional thermodynamic vehicle. Pol. J. Agron. 2009, 1, 15-18.

38. Cordell, D.; Drangert, J.O.; White, J.M. The story of phosphorus: Global food security and food for thought. Glob. Environ. Chang. 2009, 19, 292-305. [CrossRef]

39. Howden, N.J.K.; Burt, T.P.; Worrall, R.; Mathias, S.M.; Whelan, M.J.V. Nitrate pollution in intensively farmed regions: What are the prospects for sustaining high-quality groundwater? Water Resour. Res. 2011, 47, 3. [CrossRef]

40. Ramankutty, N.; Seufert, V.M.; Foley, A.J. Comparing the yields of organic and conventional agriculture. Nature 2012, 485, 229-232.

41. Woods, J.; Williams, A.; Hughes, J.K.; Black, M.; Murphy, R. The future of the global food system. Philos. Trans. R. Soc. 2010, 365, 2991-3006. [CrossRef] [PubMed]

42. Ramankutty, N.; Amato, T.E.; Monfreda, C.; Foley, J.A. Farming the planet: Geographic distribution of global agricultural lands in the year 2000. Glob. Biogeochem. Cycles 2008, 22, 19. [CrossRef]

43. Mousazadeh, H.; Keyhani, A.; Mobli, H.; Bardi, U.; El Asmar, T. Sustainability in agricultural mechanization: Assessment of a combined photovoltaic and electric multipurpose system for farmers. Sustainability 2009, 1, 1042-1068. [CrossRef]

44. Kotilainen, K.; Saari, U.A. Policy Influence on Consumers' Evolution into Prosumers-Empirical Findings from an Exploratory Survey in Europe. Sustainability 2018, 10, 186. [CrossRef]

45. Jasiński, J.; Kozakiewicz, M.; Sołtysik, M. Determinants of Energy Cooperatives' Development in Rural Areas-Evidence from Poland. Energies 2021, 14, 319. [CrossRef]

46. Zhao, Z.; Chang, R.; Chen, Y. What hinder the further development of wind power in China? A socio-technical barrier study. Energy Policy 2016, 88, 465-476. [CrossRef]

47. Burningham, K.; Barnett, J.; Walker, G. An array of deficits: Unpacking NIMBY discourses in wind energy developers' conceptualizations of their local opponents. Soc. Nat. Resour. 2015, 28, 246-260. [CrossRef] 
48. Wirth, S. Communities matter: Institutional preconditions for community renewable energy. Energy Policy 2014, 70, 236-246. [CrossRef]

49. Parag, Y.; Sovacool, B.K. Electricity market design for the prosumer era. Nat. Energy 2016, 1, 16032. [CrossRef]

50. Bleicher, A.; Gross, M. User motivation, energy prosumers, and regional diversity: Sociological notes on using shallow geothermal energy. Geotherm. Energy 2015, 3, 12. [CrossRef]

51. Shove, E. Converging conventions of comfort, cleanliness and convenience. J. Consum. Policy 2003, 26, 395-418. [CrossRef]

52. Kotler, P. Prosumers: A New Type of Consumer. Futurist 1986, 20, $24-28$.

53. Olkkonen, L.; Korjonen-Kuusipuro, K.; Gronberg, I. Redefining a stakeholder relation: Finnish energy "prosumers," as coproducers. Environ. Innov. Soc. Transit. 2016, 24, 57-66. [CrossRef]

54. Ellsworth-Krebs, K.; Reid, L. Conceptualising energy prosumption: Exploring energy production, consumption and microgeneration in Scotland, UK. Environ. Plan. A 2016, 48, 1988-2005. [CrossRef]

55. Cadoret, I.; Padovano, F. The political drivers of renewable energies policies. Energy Econ. 2016, 56, 261-269. [CrossRef]

56. Soeiro, S.; Dias, M.F. Renewable energy community and the European energy market: Main motivations. Heliyon 2020,6 , e04511. [CrossRef]

57. Hargreaves, T.; Hielscher, S.; Seyfang, G.; Smith, A. Grassroots innovations in community energy: The role of intermediaries in niche development. Glob. Environ. Chang. 2013, 23, 868-880. [CrossRef]

58. Seyfang, G.; Hielscher, S.; Hargreaves, T.; Martiskainen, M.; Smith, A. A grassroots sustainable energy niche? Reflections on community energy in the UK. Environ. Innov. Soc. Transit. 2014, 13, 21-44. [CrossRef]

59. Yildiz, Ö.; Rommel, J.; Debor, S.; Holstenkamp, L.; Mey, F.; Müller, J.R.; Radtke, J.; Rognli, J. Renewable energy cooperatives as gatekeepers or facilitators? Recent developments in Germany and a multidisciplinary research agenda. Energy Res. Soc. Sci. 2015, 6, 59-73. [CrossRef]

60. Moroni, S.; Alberti, V.; Antoniucci, V.; Bisello, A. Energy communities in the transition to a low-carbon future: A taxonomical approach and some policy dilemmas. J. Environ. Manag. 2019, 236, 45-53. [CrossRef]

61. Heiskanen, E.; Johnson, M.; Robinson, S.; Vadovics, E.; Saastamoinen, M. Low- carbon communities as a context for individual behavioural change. Energy Policy 2010, 38, 7586-7595. [CrossRef]

62. Hoffman, S.M.; High-Pippert, A. Community energy: A social architecture for an alternative energy future. Bull. Sci. Technol. Soc. 2005, 25, 387-401. [CrossRef]

63. Johnson, V.C.A.; Hall, S. Community energy and equity: The distributional implications of a transition to a decentralised electricity system. People Place Policy 2014, 8, 149-167. [CrossRef]

64. Hain, J.J.; Ault, G.W.; Galloway, S.J.; Cruden, A.; McDonald, J.R. Additional renewable energy growth through small-scale community orientated energy policies. Energy Policy 2005, 33, 1199-1212. [CrossRef]

65. Hall, S.; Foxon, T.J.; Bolton, R. Financing the civic energy sector: How financial institutions affect ownership models in Germany and the United Kingdom. Energy Res. Soc. Sci. 2016, 12, 5-15. [CrossRef]

66. Heaslip, E.; Costello, G.J.; Lohan, J. Assessing good-practice frameworks for the development of sustainable energy communities in Europe: Lessons from Denmark and Ireland. J. Sustain. Dev. Energy Water Environ. Syst. 2016, 4, 307-319. [CrossRef]

67. Bristow, G.; Cowell, R.; Munday, M. Windfalls for whom? The evolving notion of 'community' in community benefit provisions from wind farms. Geoforum 2012, 43, 1108-1120. [CrossRef]

68. Burke, M.J.; Stephens, J.C. Political power and renewable energy futures: A critical review. Energy Res. Soc. Sci. 2018, 35, 78-93. [CrossRef]

69. Campbell, B.; Cloke, J.; Brown, E. Communities of energy. Econ. Anthropol. 2016, 3, 133-144. [CrossRef]

70. Curtin, J.; Mclnerney, C.; Johannsdottir, L. How can financial incentives promote local ownership of onshore wind and solar projects? Local Econ. 2018, 33, 40-62. [CrossRef]

71. Kellett, J. Community-based energy policy: A practical approach to carbon re- duction. J. Environ. Plann. Manag. 2007, 50, 381-396. [CrossRef]

72. Koirala, B.P.; Koliou, E.; Friege, J.; Hakvoort, R.A.; Herder, P.M. Energetic communities for community energy: A review of key issues and trends shaping integrated community energy systems. Renew. Sustain. Energy Rev. 2016, 56, 722-744. [CrossRef]

73. Koirala, B.P.; Araghi, Y.; Kroesen, M.; Ghorbani, A.; Hakvoort, R.A.; Herder, P.M. Trust, awareness, and independence: Insights from a socio-psychological factor analysis of citizen knowledge and participation in community energy systems. Energy Res. Soc. Sci. 2018, 38, 33-40. [CrossRef]

74. Kunze, C.; Becker, S. Collective ownership in renewable energy and opportunities for sustainable degrowth. Sustain. Sci. 2015, 10, 425-437. [CrossRef]

75. McKenna, R. The double-edged sword of decentralized energy autonomy. Energy Policy 2018, 113, 747-750. [CrossRef]

76. Romero-Rubio, C.; de Andres Diaz, J.R. Sustainable energy communities: A study contrasting Spain and Germany. Energy Policy 2015, 85, 397-409. [CrossRef]

77. Sanguinetti, A. The design of intentional communities: A recycled perspective on sustainable neighborhoods. Behav. Soc. Issues 2012, 21, 5-25. [CrossRef]

78. Schafer, M.; Hielscher, S.; Haas, W.; Hausknost, D.; Leitner, M.; Kunze, L.; Mandl, S. Facilitating low-carbon living? A comparison of intervention measures in different community-based initiatives. Sustainability 2018, 10, 1047. [CrossRef] 
79. Seyfang, G.; Park, J.J.; Smith, A. A thousand flowers blooming? An examination of community energy in the UK. Energy Policy 2013, 61, 977-989. [CrossRef]

80. Sperling, K. How does a pioneer community energy project succeed in practice? The case of the Sams0 Renewable Energy Island. Renew. Sustain. Energy Rev. 2017, 71, 884-897. [CrossRef]

81. Walker, G.; Devine-Wright, P. Community renewable energy: What should it mean? Energy Policy 2008, 36, 497-500. [CrossRef]

82. Walker, G.; Devine-Wright, P.; Hunter, S.; High, H.; Evans, B. Trust ad community: Exploring the meanings, context and dynamics of community renewable energy. Energy Policy 2010, 38, 2655-2663. [CrossRef]

83. van der Schoor, T.; Scholtens, B. Power to the people: Local community initiatives and the transition to sustainable energy. Renew. Sustain. Energy Rev. 2015, 43, 666-675. [CrossRef]

84. Wiseman, H.J.; Bronin, S.C. Community-scale renewable energy. San Diego J. Clim. Energy Law 2013, 14, 1-29.

85. Bomberg, E.; McEwan, N. Mobilizing community energy. Energy Policy 2012, 51, 435-444. [CrossRef]

86. Boon, F.P.; Dieperink, C. Local civil society based renewable energy organisations in The Netherlands: Exploring the factors that stimulate their emergence and development. Energy Policy 2014, 69, 297-307. [CrossRef]

87. Petersen, J.P. Energy concepts for self-supplying communities based on local and renewable energy sources: A case study from northern Germany. Sustain. Cities Soc. 2016, 26, 1-8. [CrossRef]

88. Susser, D.; Doring, M.; Ratter, B.M.W. Harvesting energy: Place and local en- trepreneurship in community-based renewable energy transition. Energy Policy 2017, 101, 332-341. [CrossRef]

89. Moroni, S.; Alberti, V.; Antoniucci, V.; Bisello, A. Energy communities in a dis- tributed energy scenario. In Green Energy and Technology; Bisello, A., Ed.; Springer: Berlin/Heidelberg, Germany, 2018; pp. 429-437.

90. Salkin, P.E. The key to unlocking the power of small scale renewable energy: Local land use regulation. J. Land Use 2012, 27, 339-367.

91. Moorthy, K.; Patwa, N.; Gupta, Y. Breaking barriers in deployment of renewable energy. Heliyon 2019, 5, 1-23. [CrossRef]

92. Papież, M.; Śmiech, S.; Frodyma, K. Determinants of renewable energy development in the EU countries. A 20-Year Perspective. Renew. Sustain. Energy Rev. 2018, 91, 918-934. [CrossRef]

93. Gorroño-Albizu, L.; Sperling, K.; Djørup, S. The past, present and uncertain future of community energy in Denmark: Critically reviewing and conceptualising citizen ownership. Energy Res. Soc. Sci. 2019, 57, 101231. [CrossRef]

94. Sovacool, B.K. Rejecting renewables: The socio-technical impediments to renewable electricity in the United States. Energy Policy 2009, 37, 4500-4513. [CrossRef]

95. Reddy, S.; Painuly, J.P. Diffusion of renewable energy technologies-barriers and stakeholders7 perspectives. Renew. Energy 2004, 29, 1431-1447. [CrossRef]

96. Michaels, L.; Parag, Y. Motivations and barriers to integrating "presuming" services into the future decentralized electricity grid: Findings from Israel. Energy Res. Soc. Sci. 2016, 21, 70-83. [CrossRef]

97. Sovacool, B.K. Renewable Energy: Economically Sound, Politically Difficult. Electr. J. 2008, 21, 18-29. [CrossRef]

98. Couture, T.; Gagnon, Y. An analysis of feed-in tariff remuneration models: Implications for renewable energy investment. Energy Policy 2010, 38, 955-965. [CrossRef]

99. Walker, G. What are the barriers and incentives for community-owned means of energy production and use? Energy Policy 2008, 36, 4401-4405. [CrossRef]

100. Middlemiss, L.; Parrish, B. Building capacity for low-carbon communities: The role of grassroots initiatives. Energy Policy 2010, 38, 7559-7566. [CrossRef]

101. Kotilainen, K.; Makinen, S.; Jarventausta, P.; Rautiainen, A.; Markkula, J. The Role of Residential Prosumers Initiating the Energy Innovation Ecosystem to Future Flexible Energy System. In Proceedings of the 2016 13th International Conference on the European Energy Market (EEM), Porto, Portugal, 6-9 June 2016.

102. Laroche, M.; Bergeron, J.; Barbaro-Forleo, G. Targeting consumers who are willing to pay more for environmentally friendly products. J. Consum. Mark 2001, 189, 503-520. [CrossRef]

103. Walker, G.P.; Hunter, S.; Devine-Wright, P.; Evans, B.; Fay, H. Harnessing community energies: Explaining and evaluating community-based localism in renewable energy policy in the UK. Glob. Environ. Politics 2007, 7, 64-82. [CrossRef]

104. Peters, M.; Fudge, S.; Sinclair, P. Mobilizing community action towards a low-carbon future: Opportunities and challenges for local government in the UK. Energy Policy 2010, 38, 7596-7603. [CrossRef]

105. Rogers, J.; Simmons, E.; Convery, I.; Weatherall, A. Public perceptions of opportunities for community-based renewable energy projects. Energy Policy 2008, 36, 4217-4226. [CrossRef]

106. Oteman, M.; Wiering, M.; Helderman, J.K. The institutional space of community initiatives for renewable energy: A comparative case study of the Netherlands, Germany and Denmark. Energy Sustain. Soc. 2014, 4, 11. [CrossRef]

107. Toke, D. Wind power in UK and Denmark: Can rational choice help explain different outcomes? Environ. Politics 2002, 11, 83-110. [CrossRef]

108. Rotmans, J.; Loorbach, D. Complexity and transition management. J. Ind. Ecol. 2009, 13, 184-196. [CrossRef]

109. Agterbosch, S.; Vermeulen, W.; Glasbergen, G. Implementation of wind energyin the Netherlands: The importance of the social-institutional setting. Energy Policy 2004, 32, 2049-2066. [CrossRef]

110. Jarventausta, P. Smart Grids with Large Scale Implementation of Automatic Meter Reading-Experiences from Finland. In The Handbook of Clean Energy Systems; John Wiley \& Sons: Hoboken, NJ, USA, 2015. 
111. Burgess, J.; Nye, M. Re-materializing energy use through transparent monitoring systems. Energy Policy 2008, $36,4454-4459$. [CrossRef]

112. Hargreaves, T. Practiceing behaviour change: Applying social practice theory to pro-environmental behaviour change. J. Consum. Cult. 2011, 11, 79-99. [CrossRef]

113. IEA-RETD. Residential Prosumers-Drivers and Policy Options (RE-Prosumers). 2014. Available online: http://iea-retd.org/wpcontent/uploads/2014/06/RE-PROSUMERS_IEA-RETD_2014.pdf (accessed on 23 August 2021).

114. Lazo, J.; McClain, K.T. Community perceptions, environmental impacts, and energy policy: Rail shipment of coal. Energy Policy 1996, 24, 531-540. [CrossRef]

115. Bauwens, T.; Gotchev, B.; Holstenkamp, L. What drives the development of community energy in Europe? The case of wind power cooperatives. Energy Res. Soc. Sci. 2016, 13, 136-147. [CrossRef]

116. Bulkeley, H.; Betsill, M. Rethinking sustainable cities: Multilevel governance and the 'urban' politics of climate change. Environ. Polit. 2005, 14, 42-63. [CrossRef]

117. Shaw, S.; Mazzucchelli, P. Evaluating the perspectives for hydrogen energy uptake in communities: Success criteria and their application. Energy Policy 2008, 38, 5359-5371. [CrossRef]

118. Alam, S.S.; Nik Hashim, N.H.; Rashid, M.; Omar, N.A.; Ahsan, N.; Ismail, M.D. Small-scale households renewable energy usage intention: Theoretical development and empirical settings. Renew. Energy 2014, 68, 255-263. [CrossRef]

119. Jaffe, A.B.; Stavins, R.N. Dynamic Incentives of Environmental Regulations: The Effects of Alternative Policy Instruments on Technology Diffusion. J. Environ. Econ. Manag. 1995, 29, S43-S63. [CrossRef]

120. Paravantis, J.A.; Stigka, E.K.; Mihalakakou, G.K. An analysis of public attitudes towards renewable energy in Western Greece. Renew. Sustain. Energy Rev. 2014, 32, 100-106. [CrossRef]

121. Jaffe, A.B.; Newell, R.G.; Stavins, R.N. A tale of two market failures: Technology and environmental policy. Ecol. Econ. 2005, 54, 164-174. [CrossRef]

122. Lipp, J. Lessons for effective renewable electricity policy from Denmark, Germany and the United Kingdom. Energy Policy 2007, 35, 5481-5495. [CrossRef]

123. Nolden, C. Governing community energy-Feed-in tariffs and the development of community wind energy schemes in the United Kingdom and Germany. Energy Policy 2013, 63, 543-552. [CrossRef]

124. Golubchikov, O.; Deda, P. Governance, technology, and equity: An integrated policy framework for energy efficient housing. Energy Policy 2012, 41, 733-741. [CrossRef]

125. Kristensson, P.; Matthing, J.; Johansson, N. Key strategies for the successful involvement of customers in the co-creation of new technology-based services. Int. J. Serv. Ind. Manag. 1991, 2, 49-65. [CrossRef]

126. Wirth, S.; Markard, J.; Truffer, B.; Rohracher, H. Informal institutions matter: Professional culture and the development of biogas technology. Environ. Innov. Soc. Trans. 2013, 8, 20-41. [CrossRef]

127. Streeck, W.; Schmitter, P. Community, market, state, and associations? The prospective contribution of interest governance to social order. Eur. Sociol. Rev. 1985, 1, 119-138. [CrossRef]

128. Baccaro, L. Civil society meets the state: Towards associational democracy? Soc. Econ. Rev. 2005, 4, 185-208. [CrossRef]

129. Jobert, A.; Laborgne, P.; Mimler, S. Local acceptance of wind energy: Factors of success identified in French and German case studies. Energy Policy 2007, 35, 2751-2760. [CrossRef]

130. Musall, F.D.; Kuik, O. Local acceptance of renewable energy—A case study from southeast Germany. Energy Policy 2011, 39, 3252-3260. [CrossRef]

131. Huybrechts, B.; Mertens, T.S. he relevance of the cooperative model in the field of renewable energy. Ann. Public Coop. Econ. 2014, 85, 193-212. [CrossRef]

132. Hvelplund, F. Innovative democracy, political economy, and the transition to renewable energy. A full-scale experiment in Denmark 1976-2013. Environ. Res. Eng. Manag. 2014, 66, 5-21. [CrossRef]

133. Rogers, E.M. Diffusion of Innovations, 1st ed.; Free Press of Glencoe: New York, NY, USA, 1962.

134. McDaniel, P.; McLaughlin, S. Security and privacy challenges in the Smart Grid. IEEE Secur. Priv. 2009, 3, 75-77. [CrossRef]

135. Mirza, U.K.; Ahmad, N.; Harijan, K.; Majeed, T. Identifying and addressing barriers to renewable energy development in Pakistan. Renew. Sustain. Energy Rev. 2009, 13, 927-931. [CrossRef]

136. Burgess, J. Sustainable consumption: Is it really achievable? Consumer Policy Review 2003, 13, 78-84.

137. Benders, R.M.J.; Kok, R.; Moll, H.; Wiersma, G.; Noorman, K.J. New approaches for household energy conservation-In search of personal household energy budgets and energy reduction options. Energy Policy 2006, 34, 3612-3622. [CrossRef]

138. Rogers, E.E.M. Diffusion of Innovations, 5th ed.; Simon \& Schuster: New York, NY, USA, 2003.

139. Simon, H.A. A Behavioral Model of Rational Choice. Q. J. Econ. 2011, 69, 99-118. [CrossRef]

140. Ryan, R.; Deci, E. Self-determination theory and the facilitation of intrinsic motivation. Am. Psychol. 2000, 55, 68-78. [CrossRef]

141. Stern, P.C.; Abel, T.D.; Stern, P.C.; Dietz, T.; Abel, T.; Guagnano, G.A.; Kalof, L. A Value-Belief-Norm Theory of Support for Social Movements: The Case of Environmentalism. Hum. Ecol. Rev. 1999, 6, 81-97.

142. Fishbein, M.; Ajzen, I. Belief, Attitude, Intention, and Behaviour: An Introduction to Theory and Research; Addision-Wesley: Reading, MA, USA, 1975.

143. Ajzen, I. From intentions to actions: A Theory of Planned Behavior. In Action-Control: From Cognition to Behavior; Beckman, J., Kuhl, J., Eds.; Springer: Berlin/Heidelberg, Germany, 1985; pp. 11-39. 
144. Davis, F.D. A Technology Acceptance Model for Empirically Testing New End-User Information Systems: Theory and Results. Ph.D. Thesis, Massachusetts Institute of Technology, Cambridge, MA, USA, 1986.

145. Venkatesh, V.; Morris, M.G.; Davis, G.B.; Davis, F.D. User acceptance of information technology: Toward a unified view. MIS Q. 2017, 27, 425-478. [CrossRef]

146. Mazzucato, M.; Semieniuk, G. Financing renewable energy: Who is financing what and why it matters. Technol. Soc. Chang. 2018, 127, 8-22. [CrossRef]

147. Moroni, S.; Antoniucci, V.; Bisello, A. Energy sprawl, land taking and distributed generation. Energy Policy 2016, 98, 266-273. [CrossRef]

148. Moroni, S. Towards a General Theory of Contractual Communities. In Cities and Private Planning; Andersson, D., Moroni, S., Eds.; Edward Elgar: Cheltenham, UK, 2014; pp. 38-65. 